\title{
Rationale and Methodology of Reprogramming for Generation of Induced Pluripotent Stem Cells and Induced Neural Progenitor Cells
}

\author{
Zuojun Tian ${ }^{1,2,3}$, Fuzheng Guo ${ }^{3}$, Sangita Biswas ${ }^{2,3, *}$ and Wenbin Deng ${ }^{2,3, *}$ \\ 1 Department of Neurology, the Institute of Guangzhou Respiratory Disease, \\ State Key Laboratory of Respiratory Disease, the First Affiliated Hospital of Guangzhou Medical University, \\ Guangzhou 510120, China; zjtian@ucdavis.edu or tianzuojun9@163.com \\ 2 Department of Biochemistry and Molecular Medicine, School of Medicine, University of California, \\ Davis, CA 95817, USA \\ 3 Institute for Pediatric Regenerative Medicine, Shriners Hospitals for Children, Sacramento, CA 95817, USA; \\ fzguo@ucdavis.edu \\ * Correspondence: sangita.biswas@ucdmc.ucdavis.edu (S.B.); wbdeng@ucdavis.edu (W.D.); \\ Tel.: +1-916-453-2221 (S.B.); +1-916-453-2287 (W.D.); Fax: +1-916-453-2288 (S.B. \& W.D.)
}

Academic Editor: Irmgard Tegeder

Received: 29 March 2016; Accepted: 14 April 2016; Published: 20 April 2016

\begin{abstract}
Great progress has been made regarding the capabilities to modify somatic cell fate ever since the technology for generation of induced pluripotent stem cells (iPSCs) was discovered in 2006. Later, induced neural progenitor cells (iNPCs) were generated from mouse and human cells, bypassing some of the concerns and risks of using iPSCs in neuroscience applications. To overcome the limitation of viral vector induced reprogramming, bioactive small molecules (SM) have been explored to enhance the efficiency of reprogramming or even replace transcription factors (TFs), making the reprogrammed cells more amenable to clinical application. The chemical induced reprogramming process is a simple process from a technical perspective, but the choice of SM at each step is vital during the procedure. The mechanisms underlying cell transdifferentiation are still poorly understood, although, several experimental data and insights have indicated the rationale of cell reprogramming. The process begins with the forced expression of specific TFs or activation/inhibition of cell signaling pathways by bioactive chemicals in defined culture condition, which initiates the further reactivation of endogenous gene program and an optimal stoichiometric expression of the endogenous pluri- or multi-potency genes, and finally leads to the birth of reprogrammed cells such as iPSCs and iNPCs. In this review, we first outline the rationale and discuss the methodology of iPSCs and iNPCs in a stepwise manner; and then we also discuss the chemical-based reprogramming of iPSCs and iNPCs.
\end{abstract}

Keywords: reprogramming; dedifferentiation; transdifferentiation; induced pluripotent stem cell; induced neural progenitor cell

\section{Introduction}

During the past decade, pluripotency has been demonstrated to restore from adult somatic cells through ectopically co-expressing defined transcription factors (TFs) that normally maintain pluripotency in stem cells. This is known as cellular reprogramming [1-3]. This technology has put the field back to the limelight and formed the "Holy Grail" of regenerative medicine. On the one hand, this discovery brought forth a paradigm shift in our understanding that the fate of somatic cells is switchable when providing specific reprogramming factors and appropriate environmental stimuli; on the other hand, it paved the way for modeling human diseases by circumventing the 
critical ethical concerns and immune rejections related to application of embryonic stem cells (ESCs) and potentially substituted ESCs for diverse clinical applications [4]. Since the pioneering study of Takahashi and Yamanaka [1], substantial progress has been made to improve both the efficiency and safety of the iPSC reprogramming. Patient- and disease-specific induced pluripotent stem cells (iPSCs) have been established via viral- or nanocarrier-based method for a number of diseases, such as multiple sclerosis [5], Alzheimer's disease [6], amyotrophic lateral sclerosis [7], spinal muscular atrophy [8], as well as Down syndrome, Parkinson disease, Huntington's disease and Duchenne and Becker muscular dystrophy [9]. However, the production of customized iPSCs is still a technical challenge, e.g., the rationale of epigenetic reprogramming and the mechanism of its low induction efficiency must be well documented before it becomes a routine technique.

Moreover, for further clinical applications, iPSCs need to be efficiently differentiated into the desired cell type because pluripotent stem cells, including iPSCs and ESCs, harbor the potential risk of teratoma formation in vivo (Table 1) [10,11]. However, the generation of sufficient amounts of differentiated cells from iPSCs for further basic and clinical applications is complicated and time-consuming. To overcome these obstacles, recent studies have prompted investigation into the possibility of reprogramming somatic cells to become target cell type by direct lineage conversion, bypassing the pluripotent state.

A number of publications have reported reprogramming of mouse and human fibroblasts into induced neural progenitor cells (iNPCs) through viral- or chemical-induced method [12,13]. The iNPCs are capable of self-renewing and differentiating into neurons and glial, holding great promise for both biomedical research and potential cell therapy. This lineage-restricted stem cell reprogramming complements the iPSC technology and circumvents the difficulty of differentiating neural cells from iPSCs. It also decreases the risk of immature tumorigenesis after the transplantation of iPSC progeny or their derivative multipotent stem cells due to potential iPSC contamination or incomplete differentiation [10,11].

Since iPSCs were generated in 2006 [1], this technology has been extensively studied from multiple perspectives, making it possible to deduce the rationale of cell fate conversion from iPSC generation although the mechanisms have not been fully understood. In this comprehensive review, we aim to outline the rationale and systematically summarize the methodology of cellular reprogramming in induction of iPSCs and iNPCs from somatic cells, as well as the limitations and pitfalls. In the last section, we also discuss the chemical-based reprogramming of iPSCs and iNPCs. Finally, we briefly discuss future perspectives on cellular transformation for clinical application. 
Table 1. Summary of viral and chemical reprogramming of induced pluripotent stem cell (iPSC) and induced neural precursor cell (iNPC).

\begin{tabular}{|c|c|c|c|c|}
\hline Items & Method & Donor Cells & Duration & Characteristics of iPSCs/iNPCs \\
\hline \multicolumn{5}{|c|}{ iPSC Studies } \\
\hline Takahashi, et al. [1] & Retrovirus & $\begin{array}{l}\text { Mouse embryonic (MEF) and } \\
\text { adult fibroblast }\end{array}$ & 16 days & Could differentiate into all three germ layers in vitro \\
\hline Takahashi, et al. [2] & Retrovirus & Adult human fibroblasts & 30 days & Could differentiate into cell types of the three germ layers in vitrc \\
\hline Hockemeyer, et al. [14] & Lentivirus + doxycycline & $\begin{array}{l}\text { Primary and secondary } \\
\text { human fibroblasts }\end{array}$ & $20-25$ days & Primary and secondary human iPSCs \\
\hline Huangfu, et al. [15] & Retrovirus +Valproic acid VPA & Human fibroblasts & 30 days & $\begin{array}{l}\text { Resemble human ESCs in pluripotency and global gene } \\
\text { expression profiles }\end{array}$ \\
\hline Shi, et al. [16] & $\begin{array}{l}\text { Retrovirus+BIX-01294, } \\
\text { BayK8644 }\end{array}$ & MEF & 14-21 days & Phenotypically and functionally similar to the classic mESCs \\
\hline Lyssiotis, et al. [17] & Retrovirus+ kenpaullone & MEF & 20 days & Generate germline-competent chimeras \\
\hline Hou, et al. [12] & $\begin{array}{l}\text { CHIR, 616452, FSK and } \\
\text { DZNep (C6FZ) }\end{array}$ & MEF and adult fibroblasts & 40 days & Differentiate into tissues of all three germ layers \\
\hline \multicolumn{5}{|c|}{ iNPC Studies } \\
\hline Kim, et al. [12] & doxycycline & $\begin{array}{l}\text { Doxycycline-inducible } \\
\text { secondary MEF }\end{array}$ & 7 days & $\begin{array}{l}\text { Lose capacity to self-renew after } 3-5 \text { passages in vitro and can no } \\
\text { differentiate into oligodendrocytes }\end{array}$ \\
\hline Their, et al. [18] & Retrovirus and lentivirus & MEF & 18 days & Differentiate into neurons, astrocytes, and oligodendrocytes. \\
\hline Lujan, et al. [19] & $\begin{array}{l}\text { doxycycline-inducible lentiviral } \\
\text { + tetO promoter }\end{array}$ & MEF & 24 days & $\begin{array}{l}\text { Tripotent in vitro, but without evidence of deriving neurons and } \\
\text { astrocytes in vivo }\end{array}$ \\
\hline Han, et al. [20] & Retrovirus & MEF & $4-5$ weeks & $\begin{array}{l}\text { Exhibit functionality similar to those of wild-type NPCs in vitro } \\
\text { and in vivo }\end{array}$ \\
\hline Ring, et al. [21] & Retrovirus & $\begin{array}{l}\text { MEF and human } \\
\text { fetal fibroblasts }\end{array}$ & 41 days & Differentiate into neurons, astrocytes, and oligodendrocytes \\
\hline Mitchell, et al. [22] & Lentivirus & adult human fibroblasts & 14 days & $\begin{array}{l}\text { Gives rise to all three major subtypes of neural cells with } \\
\text { functional capacity }\end{array}$ \\
\hline Lee, et al. [23] & $\begin{array}{l}\text { Lentivirus + SB431542, Noggin, } \\
\text { DN-193189, CHIR99021 }\end{array}$ & $\begin{array}{l}\text { Human cord blood or adult } \\
\text { peripheral blood cells }\end{array}$ & 10-14 days & $\begin{array}{l}\text { Produce astrocytes and oligodendrocytes and multiple } \\
\text { neuronal subtypes }\end{array}$ \\
\hline Wang, et al. [24] & $\begin{array}{l}\text { episomal vectors + microRNA + } \\
\text { CHIR99021, PD0325901, A83-01, } \\
\text { thiazovivin and DMH1 }\end{array}$ & human urine cells & 15 days & differentiated into neurons and glial cells in vitro \\
\hline Cheng, et al. [13] & VPA, CHIR99021 and Repsox & MEFs and human urinary cells & $\begin{array}{l}\text { Mouse } 10 \text { days; } \\
\text { Human, } 20 \text { days }\end{array}$ & $\begin{array}{l}\text { Mouse tripotent iNPCs; Human iNPC could differentiate into } \\
\text { neurons and astrocytes }\end{array}$ \\
\hline
\end{tabular}




\section{Rationale of Reprogramming to Induced Pluripotent Stem Cells (iPSCs)}

\subsection{The Nature of Cellular Reprogramming}

To date, reprogrammed cells can be generated through the following four approaches: (a) nuclei transfer [25]; (b) cell-to-cell fusion [26]; (c) cell extracts reprogramming [27]; and (d) direct reprogramming [1,2]. Among the above methods, direct reprogramming is highlighted in this review because it provides an avenue to induce a desired cell type just by introducing a set of known TFs to donor cells via epigenetic reprogramming without actually altering the gene sequence [28]. Thus cellular reprogramming is essentially a process to switch a cell fate from a donor cell to a desired cell. The idea to explore the induction of iPSCs initially stemmed from the somatic cell nuclear transfer (SCNT) research [29-31], in which the non-split nuclei from quiescent donor somatic cells were transferred into enucleated oocytes in metaphase II. After full reprogramming by the undefined factors in the recipient oocyte cytoplasm, the nuclei restored a totipotent state and finally gave birth to the sheep Dolly [29]. Although Yamanaka's group initially completed the landmark studies of generating iPSCs from mouse by forced expression of the four TFs: Oct4, Sox2, Klf4, and c-Myc ("OSKM") [1,2], the human fibroblasts could not be converted into iPSCs by transduction of retroviral OSKM under the culture condition for mouse ESCs [2]. This indicated that without an appropriate extrinsic environment, the human iPSCs would not be produced. Altogether, these data indicated that the induction of reprogrammed cells can only be completed by orchestrated interactions between the intrinsic factors such as expression endogenous genes, and the extrinsic factors including the stimuli from both cytoplasm and extracellular microenvironment.

\subsection{Intrinsic and Extrinsic Factors during iPSC Reprogramming}

IPSCs can only be induced under an optimized conditions defined by a combination of both, intrinsic and extrinsic factors. In the research of generating iPSCs using a doxycycline-inducible lentiviral system with OSKM, the "secondary" iPSCs were generated using only doxycycline treatment from many "secondary" cells from cell line known as NGFP2 line, but not from NNeo line which has very low levels of Sox2 and Klf4. This indicated that under suboptimal levels of intrinsic factors (low levels of Sox2 and Klf4), the "secondary" iPSCs will not be induced by an opportune extrinsic factor (doxycycline treatment); and after additional transduction with Sox2 and Klf4, faithful "secondary" iPSCs were also produced from NNeo lines [32]. Additionally, the cell plating density had a profound effect on iPSC formation, both low and high plating densities could entirely inhibit iPSC colony formation, suggesting that in the case of improper extrinsic factor (cell plating densities), the "secondary" iPSCs will also not be generated by proper intrinsic factors (endogenous pluripotency genes) [32]. Particularly, there was another interesting phenomenon observed in iPSCs induction. The "primary" reprogramming efficiency of human iPSCs from fibroblasts was significantly less than that of mouse cells $(\sim 0.002 \%$ vs. $\sim 0.06 \%$, respectively); however, the reprogramming efficiency between "secondary" human and mouse iPSCs was in the same range ( $2 \% v s . \sim 4 \%$, respectively) $[32,33]$. These data indicated that the interactions of similar intrinsic factors (endogenous pluripotency genes in "secondary" fibroblasts) and the similar external environment (in cell culture condition) can produce a similar reprogramming efficiency between different species. As a result, the appropriate levels of both intrinsic and extrinsic factors are equally important in the process of cell fate reprogramming, both are indispensable.

\subsection{Stoichiometric Expression of Endogenous Pluripotency Genes in iPSC Reprogramming}

It is now apparent that only when all endogenous pluripotency genes are expressed at optimal levels, then iPSCs can be generated. Cowan et al. [34] demonstrated that keratinocyte-derived primary iPSC colonies first appeared at the 18th days, and afterward the reprogramming efficiency appeared to decline with the length of doxycycline exposure. In addition, the "secondary" fibroblasts with high transgenic expression of Sox 2 showed only moderate reprogramming efficiency due to 
increased cell death, and those with very low levels of Sox2 and Klf4 could not be expanded to "secondary" iPSCs [32,33]. Yamaguchi et al. (2011) [35] also revealed that Sox2 played a vital role in a dose-dependent manner in producing iPSCs, lower Sox2 expression resulting in higher efficiency in general. Papapetrou et al. (2009) [36] further demonstrated that high Oct4 expression and low Sox2 expression led to the highest efficiency; Oct4 activated the mesodermal gene expression and suppressed ectodermal gene expression, and on the contrary, Sox 2 facilitated ectodermal gene expression and lowered mesodermal gene transcription [35,36]. Predominantly, the high Oct4 and low Sox 2 stoichiometry is probably required throughout the entire process of reprogramming; when all the endogenous genes are expressed, the endogenous Oct4 levels are still high, whereas Sox2 levels remain low $[37,38]$, which was proved to be a "see saw model" of balance to facilitate cells reaching full pluripotent states [39]. Any imbalance of the linage specific factors produced an undesirable fate and failure to become iPSCs.

Collectively, the rationale for generating iPSCs can be summarized as such that, it is in nature a process to restore the pluripotency to a somatic cell, which begins with the forced expression of suitable exogenous transgenes/the activity of bioactive chemicals or drugs in opportune extrinsic environment, and more importantly initiates the further reactivation of endogenous pluripotency program and an optimal stoichiometric expression of all the endogenous pluripotency genes, which finally leads to generation of iPSC (Figure 1).

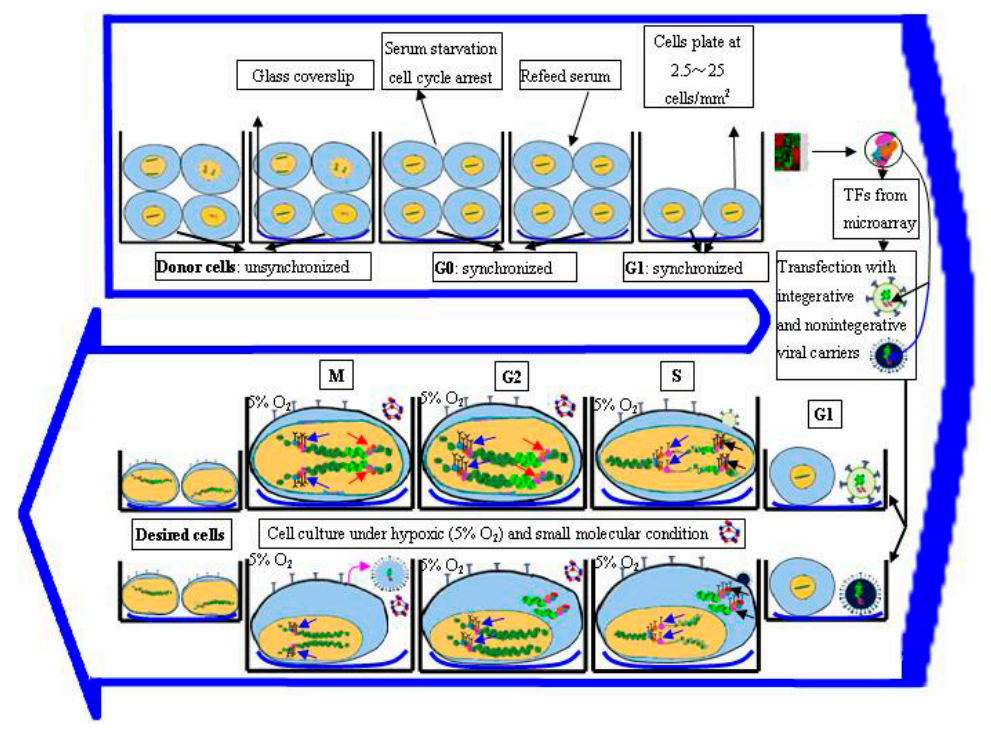

Figure 1. Reprogramming is the process of switching a cell fate from a donor cell to a desired cell, needing orchestrated interactions between the intrinsic factors of endogenous genes and the extrinsic factors from culture microenvironment such as optimal cell plating density, glass coverslip, appropriate small molecules, and hypoxic conditions, e.g., $5 \% \mathrm{O}_{2}$. The donor cells are induced to cell cycle arrest at Gap 0 (G0) phase by transient serum starvation, and synchronized state to reenter cell cycle after re-feeding with serum. At Gap 1 (G1) phase, the donor cells are transduced with integrative or nonintegrative viral carriers, and returned to a transient Synthesis (S) phase. During $S$ phase the exogenous transcription factors (TFs) from microarray data are transcribed and synthesized (black arrows), initiating endogenous pluripotency/multipotency gene expression (blue arrows). The integrative viral expression is within nucleus, and nonintegrative viral expression is in the cytoplasm. During Gap 2 (G2) phase, nucleosomes mature and histone biogenesis is repressed; the endogenous genes are further expressed to appropriate levels (blue arrows), simultaneously, the extrinsic viral TFs begin to be inhibited (red arrows). During Mitosis (M) phase, many TFs and chromatin binding proteins are ejected from the chromatin; the integrative viruses are gradually silenced, and the nonintegerative viral TFs are gradually removed from host cells (purple arrow). Finally, the desired cells such as induced pluripotent stem cells (iPSCs) and induced neural progenitor cells (iNPCs) are induced [13,26,33,40]. 


\section{Methodology of Reprogramming to iPSCs}

After the fundamental studies of Yamanaka and coworkers, numerous strategies have been reported to improve the efficiency and safety of iPSC generation. The strategies are mainly explored from the following aspects of iPSC induction: (1) screening of candidate TFs; (2) transduction of donor cells with TFs; (3) activation of endogenous pluripotency genes; (4) regulation of cell cycle status; (5) optimization of cell culture environment; and (6) screening of small molecules, also termed chemical-based reprogramming, which will be discussed in the last section for both iPSCs and iNPCs reprogramming (Figure 1).

\subsection{Screening of Candidate Transcription Factors (TFs)}

Screening for candidate reprogramming factors (TFs) is a key step in direct reprogramming. The logic to select candidate TFs were on the basis of the Yamanaka's hypothesis that the factors responsible for maintenance of pluripotency in ESCs are also important in inducing pluripotency in somatic cells [1]. The identification of TFs in documented papers generally followed a stepwise process, which fell into two modes: (1) A stochastic mode, in which the candidate TFs were pick from published papers, or by identifying the function of ESC-specific genes. Initially, Yamanaka and coworkers stochastically selected 24 genes as candidate factors from documents to induce pluripotency. Following a comprehensive process of systematic elimination, the combination of bona fide OSKM factors was finally identified sufficient to induce mouse iPSCs [1], and then human iPSCs [2]; (2) In the deterministic mode, TFs were selected from transcriptome database based on DNA microarray data. In 2013, induced mouse oligodendrocyte progenitor cells (iOPCs) were reported by two papers using combinations of reprogramming factors Sox10, Olig2, plus Nkx6.2 or Zfp536 [41,42]. Both of the two studies used microarray data to deterministically identify TFs candidates, which were greatly expressed in OPCs and oligodendrocytes comparable to other neural lineages with knowing roles during oligodendroglia development. Dissecting the functions of the candidate transcription factors is critical in selection process. For iPSC generation, it was known that Oct $3 / 4$ and Sox 2 act as core transcription factors of pluripotency networks by modulating the expression of pluripotency-associated genes; Myc was known as proto-oncogene which encouraged cellular proliferation and survival; Klf4, similarly to Homeobox Transcription Factor Nanog NANOG, could provoke leukemia inhibitory factor LIF-independent self-renewal [3]. In the process of reprogramming to iPSCs, Oct4 and Sox2 are initially linked with distal elements of silent genes [43] that are mainly targeted by c-Myc and Klf4 at their promoters either by opening chromatin de novo or by maintaining the active mark [43,44], which consequently lead to a general expression of genes [43-47]. Single-cells conversion further showed that Oct4 is mainly responsible for cell proliferation, and Sox 2 is indicative of cell pluripotency [37].

Some reprogramming genes can be functionally substituted with divergent factors. Soon after the discovery of OSKM, another combination of factors Oct4, Sox2, Nanog, and Lin28 was also found to be able to reprogram somatic cells to pluripotency [48]. Subsequent studies also successively showed that OSKM can be respectively replaced with Nr5a2, Sox1, Esrrb and Glis-1 [49-54].

The core reprogramming factors remain highly conserved between different species. The typical example is that OSKM can be used to generate iPSCs form both mouse and human fibroblasts [1,2]; and the single factor Sox 2 can directly induce mouse and human iNPCs from respective fibroblasts [21]. These data indicated that the fundamental transcriptional network administrating pluri- and multi-potency is extremely preserved in human and mouse. The comparative studies of gene expression networks further revealed that the conservation of gene expression among human and mouse are mainly in the transcriptional and pathway alteration responses and its constituting substructures still have some divergences [55,56]. Consequently, in the future, direct lineage reprogramming of human, may utilize the same core TFs that of mouse of murine, but the modifying factors and culture conditions may be different. 


\subsection{Transfection of Transcription Factors}

A variety of methods have been documented to deliver TFs to donor cells for iPSCs generation, most of which relied on biological-, chemical- or physical-based delivery system for transfection (Figure 2). Biological-based delivery uses viral-based carriers including integrative (retrovirus and lentivirus) and nonintegrative viral vectors (adenovirus, Epstein-Barr (EB) and Sendai virus). Chemical-based delivery mainly includes nanocarriers, which contain DNA-, RNA- and protein-based carriers. They are usually regarded as alternatives for viral transduction owing to their delivery of larger transgene, low immunogenicity, easy transfection as well as low risk of gene integration and insertional mutagenesis $[57,58]$. However, their efficiency and stability remain to be improved. Physical-based delivery involves electroporation, and is seldom reported as successful in reprogramming.

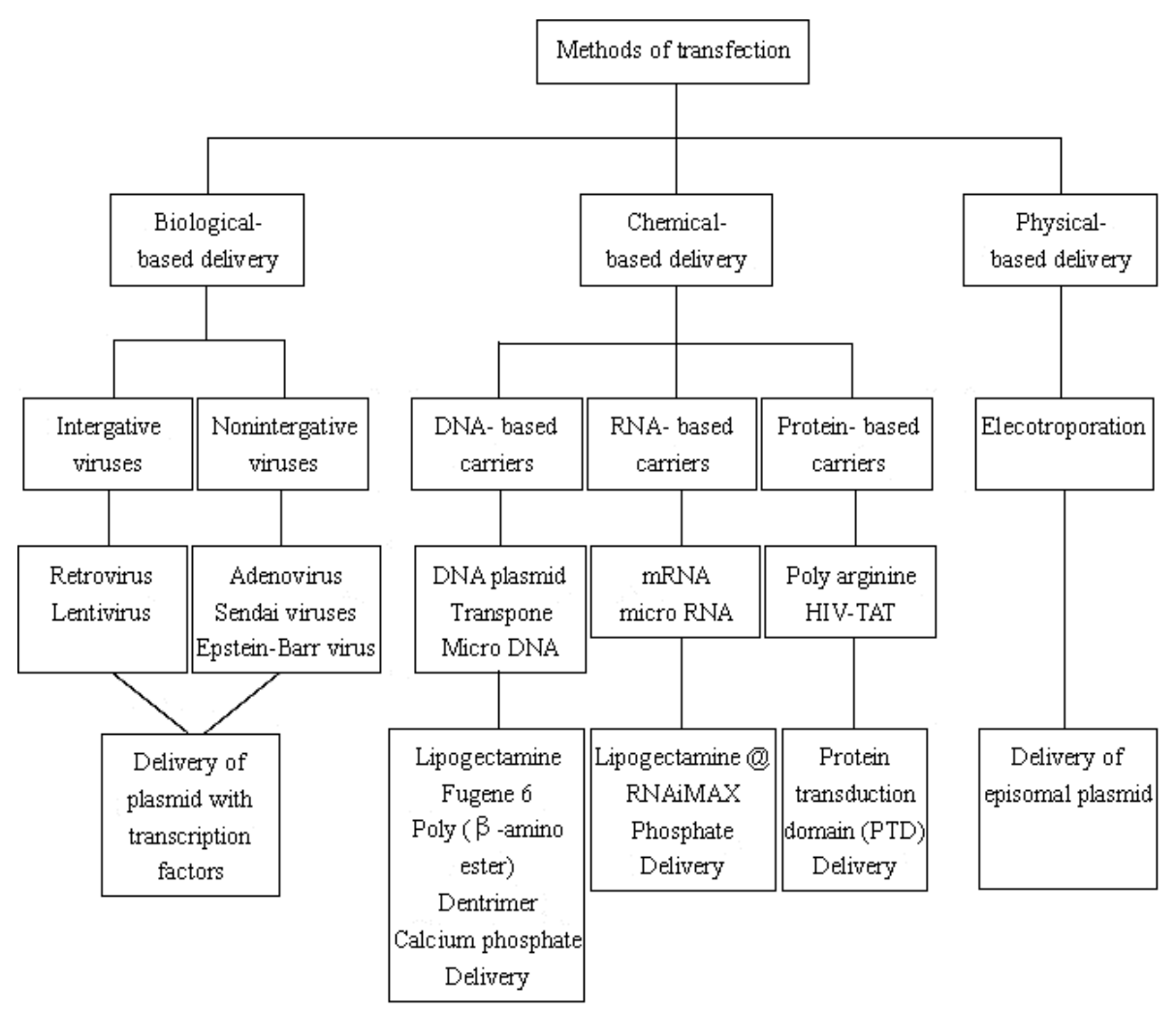

Figure 2. Flow chart outlining the various methods of transfection in induction of iPSCs. These methods are generally classified into biological-, chemical- and physical-based reprogramming.

\subsubsection{Biological-Based Delivery System}

Retrovirus and lentivirus both belong to integrating vectors, however, the latter can infect a broader spectrum of host cells, including actively proliferating cells, terminally differentiated cells and primary cells such as the myocyte or the neuron [28,59-61]. Retrovirus was firstly used for iPSCs conversion via introducing OSKM into mouse and human fibroblasts [1,2]. The doxycycline inducible lentiviral gene expression system was used to generate "primary" and "secondary" iPSCs from diverse murine and human somatic cells [32-34]. Integrating viruses however, have drawbacks of insertional mutagenesis, reactivation of transgenes and uncontrolled silencing, which prompted nonintegrating viruses to be a safer method for iPSCs generation.

Adenovirus, one kind of nonintegrating carriers, has been regarded as safer method for in induction of mouse and human iPSCs $[62,63]$. However, it caused rapid multiple organ failure and death of a patient by its high immunogenicity at a clinical trial in 1999 [64]. Sendai virus replicates 
and transcribes in the cytoplasm of infected cells, and certainly does not integrate into the host genome. Adenovirus has been used to produce iPSCs from human fibroblasts and cord blood cells free of transgene footprints $[40,65]$. By comparison with other viral carrier, Sendai viral vectors might meet the complex requirements for direct reprogramming, but its enzymes are sometimes not sensitive enough to initiate/complete the reprogramming process [66]. Epstein-Barr virus is far less immunogenic, and has effectively induced human iPSCs free of genomic integration [67], indicating EB viruses may be well-suited for clinical translation. Nevertheless, the clinical applications are obstructed by using viral vectors due to the risk of mutagenesis and immunogenicity, and field has shifted towards the chemical and physical non-integrating strategies.

\subsubsection{Chemical-Based Delivery System}

DNA-based delivery mainly includes plasmid DNA and minicircle DNA vectors. Plasmid DNA encoding TFs can also be employed for direct conversion of somatic cells. Among them, transposon is a circular plasmid DNA molecule, known as a jumping gene, translocating from one DNA site to another site [68]. Nanoparticles such as Fugene 6, has also been used in generating mouse iPSCs [1]. Minicircle DNA vectors were applied to establish footprint-free iPSC lines [69], but with 10-fold less efficiency than viral-based methods [70].

RNA-based delivery is mostly comprised of synthetic mRNA and micro RNA. Nanoparticles such as Lipofectamine ${ }^{\circledR}$ RNAiMAX, are frequently used to transfect mRNA [28], although at a lower [71] reprogramming rate than that of Sendai, EB and lentiviral reprogramming. However, when using Micro RNA (miRNA) and mRNA transfection, the success rate improved significantly to $73 \%$, similar to other approaches. Additionally, introduction of miR-302s and miR-369s could induce cell reprogramming [72]. Compared to DNA-based delivery, RNA-based carriers can be translated almost instantly in cytoplasm and regarded as a non-gene therapy for not altering the host genome [73]. Nevertheless, they are short half-life, transient expression, and with apparent immunogenicity.

Protein-based delivery, termed as protein transduction domain (PTD), refers to cell penetrating peptides (CPPs), including poly arginine and the human immunodeficiency virus transactivator of transcription (HIV-TAT). Poly arginine consisting of 11 consecutive arginines (abbreviated as 11R) with OSKM were used to induce mouse iPSCs [74]. In 2012, HIV-TAT PTDs were first time utilized to reprogram human iPSCs compared to 11RPTD, indicating TAT-TFs were transcriptionally more active than the corresponding 11R-TFs, but less than retroviral-TFs. Moreover, after linking with cationic liposomes, HIV-TAT transduction was capable of significantly increasing the efficiency by a 1000-fold [75]. These signatures of recombinant TFs may facilitate the clinical application and genetic material-free human iPSCs.

\subsubsection{Physical-Based Delivery System}

Electroporation: In this technique, an electrical field is employed to increase the permeability of the cell membrane to allow chemicals, drugs, or DNA across the cell membrane via nano-size pores [76]. In 2013, Green and colleagues reported that electroporation method produced faithful iPSCs faster than poly ( $\beta$-amino ester) [77]. Two years later, another group further revealed that Mesenchymal-to-Epithelial Transition occurring at approximately 6-12 days after electroporation in the process of reprogramming to iPSCs [78]. Electroporation has many advantages such as its technical simplicity, the ability to transiently or stably transfect whole populations of cells and its broad application for transfer of any macromolecule. Unfortunately, there are only few papers successfully using electroporation in cell fate reprogramming to date.

\subsection{Activation of Endogenous Pluripotency Genes}

Activating the expression of endogenous pluripotency genes is a key step in generation of iPSCs. Hotta et al. (2008) [79] demonstrated that pluripotent cells, different from somatic cells, have a capability to silence retroviruses by de novo DNA methylation and other mechanisms. Partly reprogrammed cells 
show partial silencing and continued expression of the retroviral OSKM genes, and fully reprogrammed cells show entire reactivation of endogenous pluripotency genes and silencing of all the viral factors. Additionally, the iPSCs induced by diverse nonintegrating deliveries such as Sendai and EB viral vectors or some nanocarriers, also showed reactivation of OSKM genes, and the carriers were all gradually eliminated during the process of reprogramming $[40,67,71]$. In particular, some iPSCs could be induced using only combination of small molecules without exogenous transgenes [17] indicating that the ability of small molecules to activate the endogenous pluripotency genes is different from viruses and nonviral carriers. Overall, faithful reprogramming is not dependent on continuous activation and expression of the exogenous transgenes, but on reestablishment of the autoregulatory loop involving the reactivation and expression of all endogenous pluripotency genes to an opportune level.

\subsection{Regulation of Cell Cycle Status for Reprogramming}

Since the first reports of iPSCs generation [1], a variety of techniques have been used to develop more efficient methods for reprogramming. However, the conversion efficiency is still very low $(0.001 \%-0.1 \%)[1,2,49,58]$. The basis for the low efficiency is weakly understood, but some studies implied the stochastic transfection and genetic heterogeneity of donor cells partially contributed to the results that only a very small fraction of infected cells ultimately converted to pluripotency $[1,2,49]$. To solve this problem, some studies have exhibited that alleviation of the cell cycle arrest, by promoting S-phase entry, could improve the reprogramming efficiency of iPSCs by achieving synchronization in donor cells [80-82] (Figure 1).

The detailed mechanism regarding the influence of cell division on reprogramming remains unclear. However, several papers demonstrated the importance of donor cell cycle in reprogramming $[83,84]$, since it is observed that self-renewal and stemness of iPSCs is reassumed during the process of donor cell division. The iPSCs, similar to ESCs, show an atypical cell cycle structure characterized by a short Gap 1 (G1)-phase and prolonged Synthesis (S) phase, which is intimately linked to the self-renewal and pluripotency and beneficial to the synthesis and expression of pluripotency genes in ESCs compared to differentiated somatic cells [85-87]. Little is known about the link between acquisition of stem cell properties and altered cell-cycle structure. A truncated G1-phase might protect ESCs from external induction of differentiation, and prolonged S-phase may be beneficial to synthesize and express the pluripotency of ESCs compared to the differentiate somatic cells $[80,81,88]$. The active promotion of the transition through S-phase might tolerate epigenetic resetting of the genome and/or encourage proliferation to increase the number of cells accessible for stochastic reprogramming. Facilitation though G1 to S-phase of cell cycle requires the stepwise phosphorylation and inactivation of retinoblastoma [89]. This phosphorylation is adjusted by cyclin dependent kinase (CDK), which needs the binding of cyclins (Сyc) for their functional activation [90]. Belmonte et al. (2011) [83] observed a 10-fold increase in the reprogramming efficiency by co-expressing $\mathrm{CycD1} / \mathrm{CDK} 4$ in BJ fibroblasts, whereas downregulation of CycD2 led to a permanent cell cycle arrest in the donor cells undergoing reprogramming, suggesting that $S$ phase offers an unrivaled opportunity to reset or reprogram gene expression profiles [84]. Chen et al. (2012) [82] utilized transient serum starvation (18 h) to induce a reversible cell cycle arrest at Gap 0 (G0) phase. After re-feeding with serum, they harvested a clear enrichment of S-phase in synchronized human dermal fibroblasts $(20 \mathrm{~h})$, and finally achieved $1.4 \%$ Nanog positive clones, which were 15-20 folds higher than unsynchronized conversion. Taken together, the cell-cycle stage of the donor cells is probably vital for successful reprogramming, and S phase provides a window of opportunity to remodel the pluripotent gene expression profiles.

Regardless of the strategy of cell cycle regulation employed in cellular reprogramming, the underlying machinery at this time is unknown. However, by studying the basic molecular activities of each phase during cell cycle, some cues feasible for the epigenetic remodeling may be found [91]. The cell cycle consists of Gap 1 (G1), Synthesis (S), Gap 2 (G2), and Mitosis (M) phase. Gap 0 (G0) refers 
to the time when a cell leaves the cycle and quit dividing, which may be a temporary resting period or more permanent. Serum starvation is frequently applied to induce a reversible cell cycle arrest at G0 phase $[29,82]$. G1, Cells produce RNA and synthesize protein in this time, ensuring everything is ready and activated for DNA synthesis. In S phase, the complete DNA instructions must be duplicated so as to produce two similar daughter cells. This stage is an essential part of cell cycle because many proteins that are involved in epigenetic inheritance such as DNA methyltransferase 1 and chromatin assembly factor-1 CAF-1, and in DNA synthesis such as DNA polymerases, replication protein A and processivity clamp proliferating cell nuclear antigen (RPA, and PCNA respectively), are known to colocalize at "replication foci" during this phase. Additionally, some enzymes, modifying histones, constantly connect with their response elements also in this period [92-95]. G2 phase serves as checkpoints to make sure everything ready to enter Mitosis (M) phase. If necessary, the cell will make proper amendment of DNA synthesis and other intracellular components. M phase, chromosomes condense, and many transcription factors and chromatin binding proteins are ejected from the chromatin. All of the cell's energy is focused on the complex and orderly division into two similar daughter cells [92]. This implies that transducing at G1 phase leading to transition through S phase may offer opportunity potential window for direct reprogramming to occur.

\subsection{Optimization of Microenvironment for Reprogramming}

Cell fate reprogramming relies not only on the roles of reprogramming genes but also on the influences of external microenvironment (culture conditions). For example variations in oxygen tension, cell-cell contact, paracrine signaling, and extracellular matrix, has received considerable attention in the epigenetic landscape and transcriptome of iPSCs conversion. Yoshida et al. (2009) [96] achieved enhanced efficiency in iPSCs reprogramming under the hypoxic condition of $5 \% \mathrm{O}_{2}$ through retroviral or even non-viral transduction. Their results were confirmed by Liu et al. [97] who produced a novel iPSCs under $3 \% \mathrm{O}_{2}$, which showed efficacy after transplanting them to ischemic stroke model in mouse. Extracellular matrix also seems to play an important role in reprogramming. For example, in reprogramming of iNPCs from mouse and human fibroblasts with Sox2, the morphology of mouse embryonic fibroblasts (MEFs) plated on gelatin coated glass coverslips were drastically changed 2-10 days after sox2-viral transduction, but remained unchanged and failed to reprogram for up to four weeks on gelatin coated plastic dishes [21]. Moreover, the efficiency of generating Nestin ${ }^{+} /$Sox $^{+}$ colonies from MEFs was greater on poly-L-ornithine/laminin-coated glass coverslips than on gelatin on Day 8 after transduction [21]. Similarly, the cell plating density also has a critical effect on iPSC formation. The plating density at $2.5 \sim 25$ cells $/ \mathrm{mm}^{2}$ showed the highest efficiency in induction of "secondary" iPSCs, both lower and higher plating densities could almost inhibit GFP+ colony development, indicating that paracrine factors might be initially required to facilitate iPSC growth, and fundamental cell proliferation will be impeded if cells are contact-inhibited before activation of the transgenes [32]. Altogether, the above-mentioned data suggest that besides reprogramming genes, the culture microenvironment is another determinant in the process of lineage reprogramming.

\section{Rationale of Reprogramming to iNPCs}

The transdifferentiation of iNPCs from fibroblasts is achieved through two different reprogramming techniques. Namely, the "indirect reprogramming" refers to use of the OSKM factors to induce iNPCs from fibroblasts, passing through an intermediate transient state by addition of specific growth factors to the reprogramming medium. "Direct reprogramming" on the other hand, means direct generation of iNPCs from fibroblasts by using lineage-specific transcription factors, bypassing the transient pluripotent stage. Here, we will discuss the rationale of both indirect and direct reprogramming to iNPCs.

"Indirect reprogramming" was first reported by Kim et al. (2011) [12]. They initially aimed to establish a more general conversion strategy to produce a broad array of unrelated desired cell types including lineage-committed precursors earlier studies demonstrated that numerous partially or 
incompletely reprogrammed cells, expressing multiple lineage-specific markers, did not show specific physiological function in the process of iPSC transdifferentiation [1,98], indicating that pluripotency may be only one of many possible outcomes of the four-factor reprogramming, and the eventual result may largely rely on extrinsic signaling conditions. Accordingly, they hypothesized that it may be possible to deliberately switch the early reprogramming process toward a defined cell type by using specific permissive signaling inputs, after which the desired cells could be obtained. Based on this hypothesis, they successfully converted fibroblasts not only into functional iNPCs, but also into spontaneously contracting cardiac cells by temporary expressing the same OSKM factors under different culture conditions. The results suggested that changing the duration of transgene expression and the culture conditions to a transient, plastic developmental state could effectively serve as a cellular platform for reprogramming toward diverse lineages. The study forms a basis of a methodology for interlineage reprogramming into multi- or oligo-potent cells.

Regarding "direct reprogramming" to iNPCs, the rationale is similar to that of transdifferentiation to iPSCs, as depending on the expression of all endogenous multipotent NPC genes, which were reactivated by extrinsic transgenes or chemicals under NPC favorable condition. However, the extrinsic transcription factors appeared to be more flexible than those of iPSCs. The iNPCs could be directly transdifferentiated from somatic cells via either Sox2-based/Sox2 alone, or Oct4-based/Oct4 alone methods, whereas the iPSCs could only be induced by OSKM factors or other functional substitutes.

\section{Methodology of Reprogramming to iNPCs}

Several strategies have been explored in the production of iNPCs, among which viral-based or chemical-based approaches have been used successfully (Figure 3). Although the physical-based method involving electroporation has been reported in a few studies to induce integration-free NPCs from human urine cells and porcine fetal fibroblasts [24,99], the nanocarrier-based methods have not yet been extensively explored in iNPC transdifferentiation. A number of studies have demonstrated that the virally-induced reprogramming of iNPCs can be achieved by three principal approaches: expression of four pluripotent factors (OSKM), expression of neural specific factors, or expression of Oct4.

In the indirect conversion to iNPCs by Kim et al. (2011) [12], they induced iNPC from doxycycline-induced "secondary" MEFs by reactivation of the typical four iPSC factors (OSKM) with doxycycline under neural reprogramming conditions. However, their iNPC had a few limitations; namely, they quickly lose their capacity to self-renew and to form colonies after 3-5 passages in vitro. Moreover they were not tripotent, and could not differentiate into oligodendrocytes. Meyer et al. (2005) [100] directly converted adult human fibroblasts into iNPCs by timely restricted expression of all OSKM factors. After 17 days, Sox2-positive neuroepithelial colonies were established, which could only be differentiated into neurons and astrocytes as well. In order to directly achieve faithful iNPCs, Thier et al. (2012) [18] used same cocktail of four iPSC factors, while limiting the Oct4 expression after the first five days during the process of transdifferentiation due to the knowledge that NPCs endogenously express only three of the four iPSC transcription factors (c-Myc, Klf4, and Sox2, but not Oct4). Eighteen days after transduction, they harvested neurosphere-like colonies for further characterization, which revealed great similarity between iNPCs and wt NPCs derived from mouse brain, indicating the crucial role of the three factors Sox2, Klf4, and c-Myc in iNPCs transdifferentiation.

In a different study, Lujan et al. (2012) [19] obtained tripotent iNPCs from mouse fibroblasts capable of differentiating into neurons, astrocytes and oligodendrocytes using a different four-factor cocktail of lentiviral Sox2, FoxG1, Pou and Brn2. This work evidently confirmed the possibility of achieving self-renewing, multipotent iNPCs using neural-specific reprogramming factors rather than iPSC-related factors. However, this method still carries a reduced risk of tumourigenesis after transplant to animal owing to the constant undifferentiated cells or transgene reactivation; meanwhile it did not show any evidence of deriving neurons and astrocytes from the iNPCs in vivo. However, in another study, Han et al. (2012) [20] induced a pure population of iNPCs using retroviral Sox2, Klf4, 
c-Myc, and Brn4 from MEFs, which showed the same epigenetic modifications and multipotentiality of wild typeNPCs. Moreover, the efficiency became higher after infection with a five-factor cocktail47). The iNPCs could be subcultured for more than 130 times, and evidenced capacity of committing both to the neuronal and to the glial lineages, without forming teratomas after transplantation. This study demonstrated once more the critical role of Sox2, Klf4, c-Myc in induction of iNPCs. However, this study focused on mouse iNPCs reprogramming, and the rate of oligodendrocyte differentiation from iNPCs requiring to be enhanced. Thereafter, new method needs to be explored to further improve the multipotency of iNPCs and to induce iNPCs from human somatic cells.
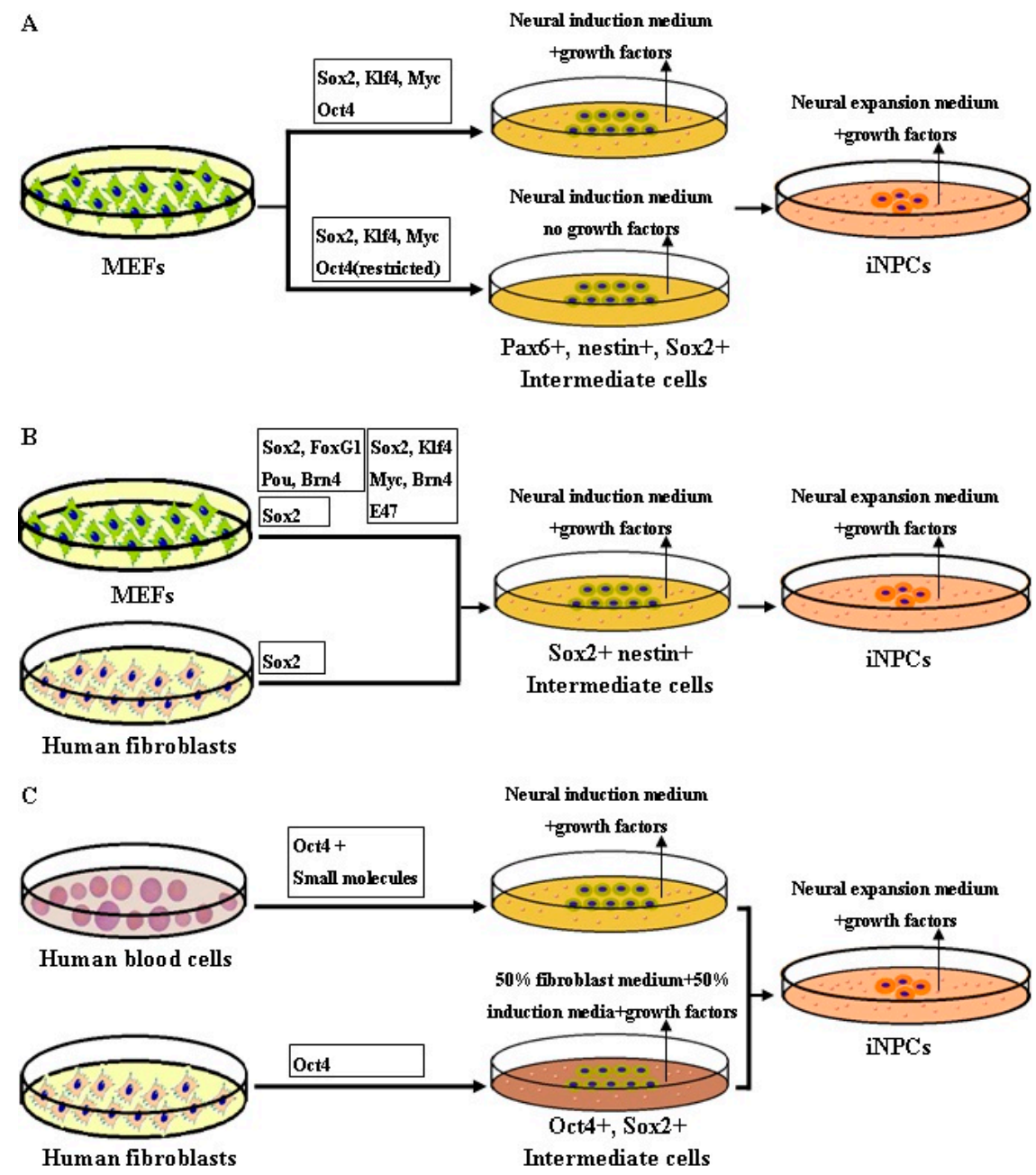

Figure 3. (A) A schematic diagram showing iNPC reprogramming from mouse embryonic fibroblasts (MEFs) using four pluripotent factors (OSKM) under neural reprogramming conditions. Neural induction medium with growth factors can deliberately switch the early iPSC reprogramming process toward NPC fate. During the process, the intermediate cells express Pax6, nestin, and Sox2 marks [12]. After restricted Oct4 expression, tripotent iNPCs were obtained without using growth factors in reprogramming medium, indicating the crucial role of the three factors Sox2, Klf4, and c-Myc in iNPCs transdifferentiation [18]; (B) the scheme of iNPC conversion from MEF and human fetal fibroblasts using neural specific factors. Sox2 and nestin were expressed in intermediate cells [19-21]; (C) a schematic showing iNPC conversion from human blood progenitors and fibroblasts via Oct4 factor in neural induction medium with growth factors. The intermediate cells express both Oct 4 and Sox 2 marks. Tripotent iNPCs can be even induced from adult human fibroblasts using Oct 4 alone, indicating iNPC could be mediated through Oct4 trajectory different from Sox2 [22,23]. 
Ring et al. (2012) [21] established a homogeneous population of iNPCs from both MEF and human fetal fibroblasts by using only a single factor, retroviral Sox2, which differentiated into neurons, astrocytes, and oligodendrocytes both in vitro and in vivo. The human iNPCs however, showed morphological and self-renewal properties, which lasted for fewer passages than mouse iNPCs. Fortunately, the human iNPCs were capable of differentiating into three main neural cell types under opportune conditions in vitro. Su et al. (2013) [101] also direct converted MEF into neural progenitor-like cells by forced growth into 3D spheres on low attachment surfaces and transfected with only a lentival Sox2 factor. These studies highlighted the crucial role of Sox 2 as a "master reprogramming gene" for producing iNPCs from differentiated cells.

Mitchell et al. (2014) [22] demonstrated that they had directly generated tri-potent neural progenitors from adult human fibroblasts using Oct-4 alone. Human Fib-NPC (Oct-4) could proliferate and express neural progenitor markers, as well as possess the potential to gives rise to three major neural subtypes, astrocytes, oligodendrocytes, and neurons with functional capacity. Their data indicated Oct4 is sufficient for inducing neural conversion from human fibroblasts. Bhatia et al. [23] enerated iNPCs from neonatal and adult peripheral blood progenitors using Oct 4 + SMAD + GSK-3 inhibitors. Interestingly, expression of Sox 2 alone failed to induce hiNPCs under these conditions, suggesting the complexity of the mechanism underlying human iNPC reprogramming.

\section{Chemical-Based Reprogramming to iPSCs and iNPCs}

Conventional viral-based reprogramming has been proved feasible for generation of iPSCs and iNSCs, however, this method carries the risks of genomic integration, mutagenesis and oncogene expression into host cells $[10,11,28]$. This has largely prevented this approach from moving towards clinical application. Since this issue also obstructs the therapeutic use of reprogrammed cells such as iPSCs and iNPCs, chemical/small molecule-based reprogramming, as an alternative strategy, has been explored (Figure 4).

In molecular biology and pharmacology, small molecules refer to the organic bioactive compounds with a low molecular weight less than 900 daltons and a size about $10^{-9} \mathrm{~m}$. Most medicines are small molecules. Compared to routine genetic methods, small molecules present several distinct merits: (1) they can rapidly regulate cell functions and even functionally replace some exogenous TFs with higher precision in a temporal and reversible manner; (2) they can be used at adjustable concentrations and combinations with tunable effects; and (3) they are nonimmunogenic, cell permeable, more cost-effective to synthesize, and easier to preserve. Simultaneously, most of chemical-mediated actions are nonspecific; a specific small molecule may work on multiple targets. This feature often presents a challenge for applying them and elucidating the effects in cell reprogramming, however, it is also an opportunity to apply them to some direct lineage reprogramming without knowing the definite reprogramming TFs. These signatures help to improve their efficacy and safety, and be potentially applied in clinical practice.

Most studies demonstrate that the general logic and strategy of using small molecules in transdifferentiation was to replace part or total of the transgenes in different cell fate reprogramming contexts without causing permanent modification to the somatic genome [102,103]. If the epigenetics of target endogenous genes can be regulated by chemicals to enter an active gene status, then there is no need to express ectopic genes [104].

The main function of small molecules in reprogramming is supposedly to activate the silent genes via modulating DNA and histone methylation as well as histone acetylation, so that they are able to undergo reactivation and transcription [105]. According to their functions during cell fate reprogramming, small molecules can be mainly assigned into the following four classes: (a) epigenetic enzyme inhibitors; (b) nuclear receptors agonists; (c) metabolic modulators; and (d) signaling pathway regulators. For more detailed reviews, please refer to Yu et al. [103] and Biswas and Jiang [104]. 
A
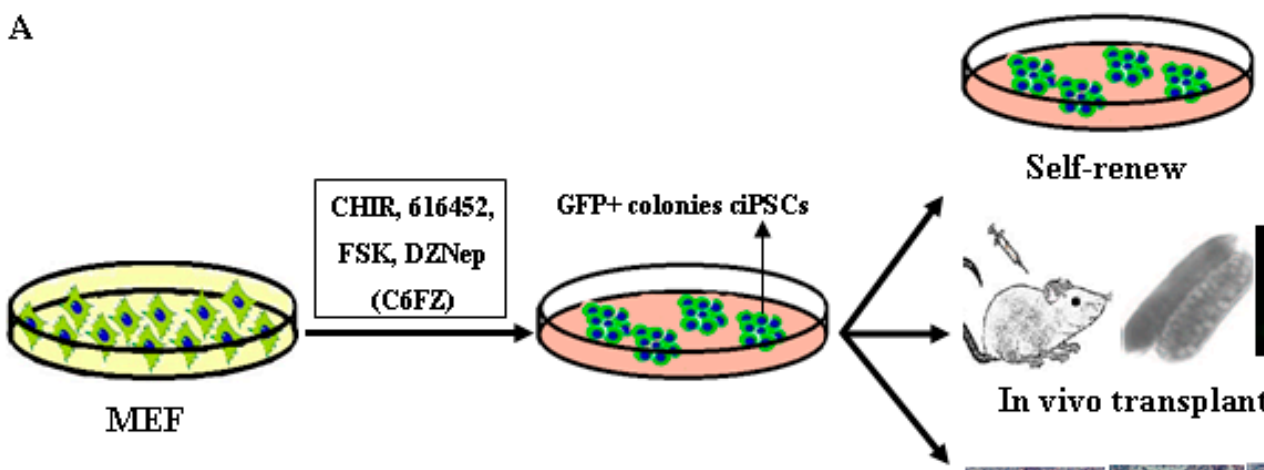

Self-renew

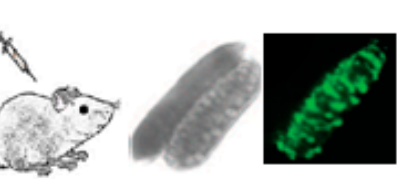

In vivo transplantation

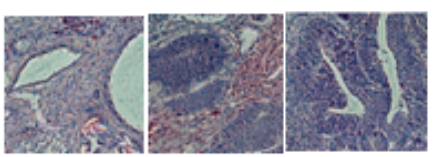

Pluripotency

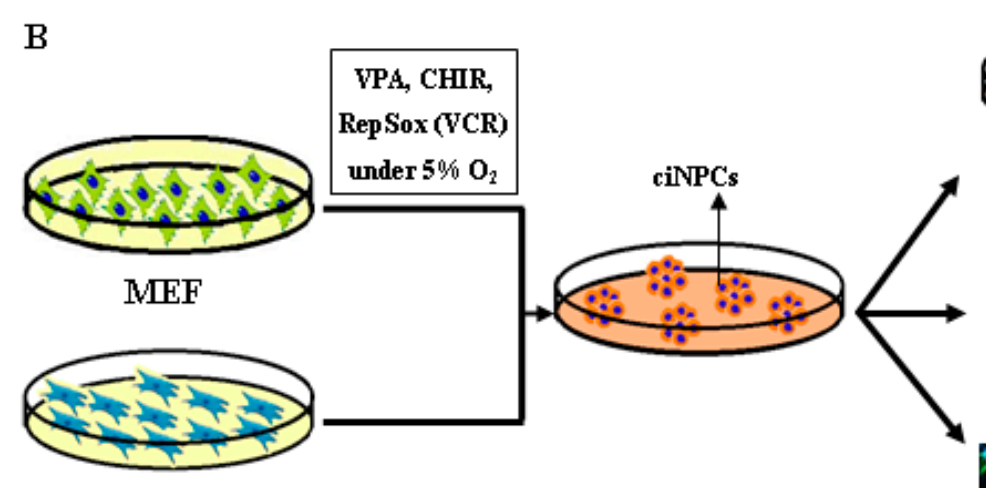

Human urine cells

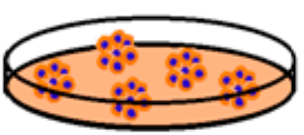

Self-renew

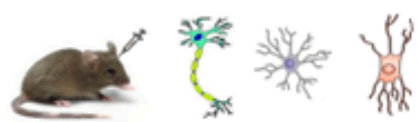

In vivo transplantation

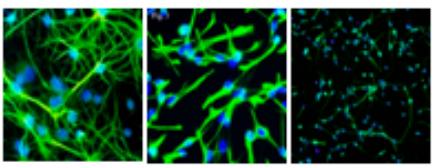

In vitro multipotency

Figure 4. Chemical-based reprogramming to chemically induced pluripotent stem cells (ciPSCs) and chemically induced neural stem cells (ciNSCs): (A) Schematics of direct iPSC transdifferentiation from mouse embryonic fibroblasts (MEF) using seven small-molecule cocktail leading to GFP-Oct4 expressing ciPSCs generation. After in vivo transplantation, the ciPSCs can differentiate into cells of all three germ layers. After screening, the four small molecules, C6FZ (CHIR99021, 616542, Forskolin and DZNep) were found to be critical in inducing CiPSCs [17]; (B) direct ciNSC reprogramming from MEFs and human urinary cells using a three small-molecule cocktail VPA, CHIR99021, and Repsox (VCR) under hypoxic condition $\left(5 \% \mathrm{O}_{2}\right)$ [13].

\subsection{Chemical-Based Reprogramming of Somatic Cells to iPSCs}

A vital epigenetic mechanism that controls gene expression is DNA methylation of the promoter. Gene promoter methylation can stably inactivate gene expression by blocking binding of cell-fate-determining TFs to the respective promoter to initiate transcription. Valproic acid (VPA), reported by Huangfu et al. [14], was the first small molecule applied to facilitate reprogramming of ciPSC, in which it could replace of the oncogenes c-Myc and Klf4 and enhance the iPSC reprogramming efficiency 100-fold over that of the OSKM method. VPA, trichostatin A (TSA), and butyrate are all histone deacetylases (HDAC) inhibitors; they can improve reprogramming and replace c-Myc via regulating lysine acetylation of histones and loosing chromatin to express transcription [106,107]. Ding et al. (2008) [15], revealed that a specific inhibitor for G9a histone methyltransferase (HMT) inhibitor BIX-01294, and BayK (a L-type calcium channel agonist) can enable MEF converting into iPSCs in the presence of Oct4 and Klf4. BIX may functionally facilitate the epigenetic switching of endogenous 
pluripotency genes from a silenced state to an active transcription state for cell fate reprogramming. Ten-eleven translocation (Tet) enzymes, convert 5-methylcytosine to 5-hydroxymethylcytosine in DNA, as the initial step in activating DNA demethylation $[108,109]$, which not only facilitate Oct4 demethylation and reactivation, but also functionally substitute exogenous Oct4 [110]. Vitamin C was shown to enhance the generation of iPSCs, at least partly owing to its Tet-dependent induction of DNA demethylation [111]. Tranylcypromine, as H3K4 demethylation inhibitors, were shown to promote iPSC generation in the absence of c-Myc [112]. DZNep, as an S-adenosylhomocysteine (SAH) hydrolase inhibitor, can reduce the total levels of histone methylation related with heterochromatin including H3K9, H3K27, and H4K20 methylation [113,114].

Nuclear receptors (NR) are ligand-regulated transcription factors. The major function of NRs is to directly bind DNA and adjust gene expression. As an orphan nuclear receptor, Nr5a2 and its close family member Nr5a1 are capable of both enhancing reprogramming and replacing Oct4 [50]; Esrrb, along with Oct4 and Sox2, can directly activate pluripotency gene Nanog [53]. Together with Nr5a2, $\mathrm{RARa} / \mathrm{g}$ greatly enhanced reprogramming kinetics and efficiency [50].

Among metabolic modulators, forskolin (FSK), a cAMP agonist, can act as a chemical substitute for Oct4 [17]. Compared with somatic cells, many stem cells depend more heavily on aerobic glycolysis. Many small molecules promote reprogramming via encouraging glycolytic metabolism and acting directly on metabolic pathways, such as fructose 2,6-bisphosphate and Quercetin. On the contrary, a glycolysis inhibitor, 2-deoxy-D-glucose, can inhibit conversion [115].

A majority of small molecules are signaling pathway regulators and thereby modulate cell transdifferentiation. Some signaling pathways even directly link to the pluripotency transcriptional network to positively regulate pluripotent state. Kenpaullone, like CHIR99021, both inhibit GSK-3 $\beta$ and enhance OSKM-based reprogramming, and Kenpaullone can also replace Klf4 [16], which is consistent with the mechanism under WNT stimulation. However since these chemicals show no cell-type specificity, they may be helpful to induce pluripotency by a general open chromatin state, but they won't be capable of directly converting a cell to another differentiated cell type.

Deng and colleagues (2013) were the first group to demonstrated generation of mouse iPSCs by a complete chemical combination of seven small-molecules, with an efficiency of $0.2 \%$ (higher than that of Yamanaka's protocol, $0.01 \%-0.1 \%$ ) [17]. After systematic identification, they demonstrated that four chemicals (C6FZ) including CHIR, 616452 (a transforming growth factor- $\beta$ inhibitor); FSK and DZNep (Z) were indispensable. This study presented the proof of principle that in the context of using small molecules, exogenous "master genes" are dispensable during cell reprogramming, indicating that pure-chemical reprogramming strategy has great potentiality in generating functional reprogrammed cells for clinical cell therapy. If human ciPSC line can be established by complete small molecule method in the near future, it will be tremendously exciting.

\subsection{Chemical-Based Reprogramming to iNPCs}

Wang et al. (2013) [24] transfected epithelial-like cells from human urine with episomal vectors carrying Oct4, Sox2, SV40LT, Klf4 and microRNA cluster MIR302-367 through electroporation, and cultured the transfected cells in presence of five chemicals: CHIR99021, PD0325901, A83-01, thiazovivin and DMH1. Fifteen days later, NSC colonies were picked up and differentiated into neurons and glial cells in vitro. Ding et al. (2014) [116] reported that ectopic expression of Oct4 combined with a chemical combination of A83-01, CHIR99021, NaB, LPA, rolipram, and SP600125, could convert AHDF into hiNPC colonies, that homogeneously expressed the neural stem cell marker PAX6, whereas ectopic expression of Sox 2 alone under the same conditions failed to produce hiNPC colonies. Similarly, Bhatia et al. [23] demonstrated that iNPCs could be obtained from human blood cells using single-factor Oct4, which could be facilitated by SMAD + GSK-3 inhibitors (SB431542, LDN-193189, Noggin, CHIR99021). Blood-derived iNPCs could differentiate into astrocytes and oligodendrocytes and multiple neuronal subtypes, including dopaminergic (central nervous system related) and nociceptive neurons (peripheral nervous system) in vitro. No detectable iNPC-like clusters 
appeared upon expression of Sox 2 alone, and efficiency of iNPC formation was significantly reduced when employed together with Oct4, indicating Sox2-mediated hiNPC transdifferentiation may follow a different trajectory from Oct4-mediated hiNPC transformation.

Pei and colleagues (2014) for the first time demonstrated the generation of chemically induced ciNPCs from both MEFs and human urinary cells by a cocktail of three chemicals: VPA, CHIR99021 and Repsox, $(\mathrm{VCR})$, under a hypoxic condition $\left(5 \% \mathrm{O}_{2}\right)$ without introducing any exogenous genes [13]. Moreover, the other inhibitors of the same pathways could also induce ciNPCs with similar efficacies. This chemical reprogramming was accompanied by activating the expression of endogenous Sox 2 . These mouse ciNPCs resembled brain-derived NPCs in both cell identities and multipotency for all three neural cell types in vitro and in vivo; nevertheless, the human hUC-derived ciNPCs could only differentiate into neurons and astrocytes, not oligodendrocytes. Han et al. (2016) [117] also reported an efficient approach to convert MEF into iNPC using a seven combination of small molecules (valproic acid, Bix01294, RG108, PD0325901, CHIR9901, vitamin C, and A83-01). The iNPCs closely resemble wild type NPC and are able to differentiate into astrocytes, functional neurons, and oligodendrocytes in vitro and in vivo. Consequently, further development and optimization of complete chemical reprogramming to produce tri-potent human ciNPCs will be promising for treating neurological diseases such as multiple sclerosis, Parkinson's disease and Alzheimer's disease.

\section{Concluding Remarks and Future Perspectives}

During the past 10 years since the generation of iPSC, significant improvements have been incorporated to increase the efficiency and safety of this technique, making it more amenable mainly for clinical applications in the fields of regenerative medicine, but also for disease modeling and therapeutic discovery. Moreover, the somatic cell reprogramming technology has also opened many avenues for direct lineage reprogramming, which bypasses the iPSC stage and thereby avoids the potential risk of teratoma development. In this context, the iNPCs have been established using viral and nonviral transduction methods. For autologous transplantation, iNPCs could be a great alternative therapy or an essential support to pharmacological treatment. iNPCs should be ideally obtained by avoiding dangerous oncogenic vectors. Compared to viruses, small molecules having their distinct advantages such as easy handling, non-immunogenicity, rapid and reversible effects, might meet the complex requirements for cell fate transformation. However, this technology is far from maturity up to now. Future directions for fate conversion greatly rely on a deeper understanding of mechanisms governing cell identity, plasticity and epigenetic regulations. Despite many challenges, exploiting chemical-based reprogramming for the purpose of generating human ciPSCs or ciNPCs through epigenetic conversion, will make this field an attractive platform to translate the work from bench to bedside for regenerative medicine.

Acknowledgments: We thank all our laboratory coworkers for inspiring discussions relevant to this review. We apologize to colleagues whose work we could not cite because of space restrictions. Work in our laboratory is supported by grants from the National Institute of Health (R01 HD087566), National Multiple Sclerosis Society, Shriners Hospitals for Children, as well as the Guangdong Natural Science Foundation (S2013010015962) and Guangdong Province Science and Technology Foundation (2013B021800282, 2014A020212350).

Author Contributions: Zuojun Tian, Sangita Biswas and Wenbin Deng decided the topic. Zuojun Tian researched the topic, wrote the manuscript and created the figures. Fuzheng Guo wrote the introduction. Wenbin Deng and Sangita Biswas wrote parts of the manuscript and also edited the manuscript.

Conflicts of Interest: The authors declare no conflict of interest.

\section{References}

1. Takahashi, K.; Yamanaka, S. Induction of pluripotent stem cells from mouse embryonic and adult fibroblast cultures by defined factors. Cell 2006, 126, 663-676. [CrossRef] [PubMed] 
2. Takahashi, K.; Tanabe, K.; Ohnuki, M.; Narita, M.; Ichisaka, T.; Tomoda, K.; Yamanaka, S. Induction of pluripotent stem cells from adult human fibroblasts by defined factors. Cell 2007, 131, 861-872. [CrossRef] [PubMed]

3. Takahashi, K.; Yamanaka, S. A decade of transcription factor-mediated reprogramming to pluripotency. Nat. Rev. Mol. Cell Biol. 2016, 17, 183-193. [CrossRef] [PubMed]

4. Selvaraj, V.; Plane, J.M.; Williams, A.J.; Deng, W. Switching cell fate: The remarkable rise of induced pluripotent stem cells and lineage reprogramming technologies. Trends Biotechnol. 2010, 28, 214-223. [CrossRef] [PubMed]

5. Song, B.; Sun, G.; Herszfeld, D.; Sylvain, A.; Campanale, N.V.; Hirst, C.E.; Caine, S.; Parkington, H.C.; Tonta, M.A.; Coleman, H.A.; et al. Neural differentiation of patient specific iPS cells as a novel approach to study the pathophysiology of multiple sclerosis. Stem Cell Res. 2012, 8, 259-273. [CrossRef] [PubMed]

6. Israel, M.A.; Yuan, S.H.; Bardy, C.; Reyna, S.M.; Mu, Y.; Herrera, C.; Hefferan, M.P.; van Gorp, S.; Nazor, K.L.; Boscolo, F.S.; et al. Probing sporadic and familial Alzheimer's disease using induced pluripotent stem cells. Nature 2012, 482, 216-220. [CrossRef] [PubMed]

7. Dimos, J.T.; Rodolfa, K.T.; Niakan, K.K.; Weisenthal, L.M.; Mitsumoto, H.; Chung, W.; Croft, G.F.; Saphier, G.; Leibel, R.; Goland, R.; et al. Induced pluripotent stem cells generated from patients with ALS can be differentiated into motor neurons. Science 2008, 321, 1218-1221. [CrossRef] [PubMed]

8. $\quad$ Ebert, A.D.; Yu, J.; Rose, F.F., Jr.; Mattis, V.B.; Lorson, C.L.; Thomson, J.A.; Svendsen, C.N. Induced pluripotent stem cells from a spinal muscular atrophy patient. Nature 2009, 457, 277-280. [CrossRef] [PubMed]

9. Park, I.H.; Arora, N.; Huo, H.; Maherali, N.; Ahfeldt, T.; Shimamura, A.; Lensch, M.W.; Cowan, C.; Hochedlinger, K.; Daley, G.Q. Disease-specific induced pluripotent stem cells. Cell 2008, 134, 877-886. [CrossRef] [PubMed]

10. Fong, C.Y.; Gauthaman, K.; Bongso, A. Teratomas from pluripotent stem cells: A clinical hurdle. J. Cell. Biochem. 2010, 111, 769-781. [CrossRef] [PubMed]

11. Yamanaka, S. A fresh look at iPS cells. Cell 2009, 137, 13-17. [CrossRef] [PubMed]

12. Kim, J.; Efe, J.A.; Zhu, S.; Talantova, M.; Yuan, X.; Wang, S.; Lipton, S.A.; Zhang, K.; Ding, S. Direct reprogramming of mouse fibroblasts to neural progenitors. Proc. Natl. Acad. Sci. USA 2011, 108, 7838-7843. [CrossRef] [PubMed]

13. Cheng, L.; Hu, W.; Qiu, B.; Zhao, J.; Yu, Y.; Guan, W.; Wang, M.; Yang, W.; Pei, G. Generation of neural progenitor cells by chemical cocktails and hypoxia. Cell Res. 2014, 24, 665-679. [CrossRef] [PubMed]

14. Huangfu, D.; Osafune, K.; Maehr, R.; Guo, W.; Eijkelenboom, A.; Chen, S.; Muhlestein, W.; Melton, D.A. Induction of pluripotent stem cells from primary human fibroblasts with only Oct4 and Sox2. Nat. Biotechnol. 2008, 26, 1269-1275. [CrossRef] [PubMed]

15. Shi, Y.; Desponts, C.; Do, J.T.; Hahm, H.S.; Schöler, H.R.; Ding, S. Induction of pluripotent stem cells from mouse embryonic fibroblasts by Oct4 and Klf4 with small-molecule compounds. Cell Stem Cell 2008, 3, 568-574. [CrossRef] [PubMed]

16. Lyssiotis, C.A.; Foreman, R.K.; Staerk, J.; Garcia, M.; Mathur, D.; Markoulaki, S.; Hanna, J.; Lairson, L.L.; Charette, B.D.; Bouchez, L.C.; et al. Reprogramming of murine fibroblasts to induced pluripotent stem cells with chemical complementation of Klf4. Proc. Natl. Acad. Sci. USA 2009, 106, 8912-8917. [CrossRef] [PubMed]

17. Hou, P.; Li, Y.; Zhang, X.; Liu, C.; Guan, J.; Li, H.; Zhao, T.; Ye, J.; Yang, W.; Liu, K.; et al. Pluripotent stem cells induced from mouse somatic cells by small-molecule compounds. Science 2013, 341, 651-654. [CrossRef] [PubMed]

18. Their, M.; Wörsdörfer, P.; Lakes, Y.B.; Gorris, R.; Herms, S.; Opitz, T.; Seiferling, D.; Quandel, T.; Hoffmann, P.; Nöthen, M.M.; et al. Direct conversion of fibroblasts into stably expandable neural stem cells. Cell Stem Cell 2012, 10, 473-479. [CrossRef] [PubMed]

19. Lujan, E.; Chanda, S.; Ahlenius, H.; Südhof, T.C.; Wernig, M. Direct conversion of mouse fibroblasts to self-renewing, tripotent neural precursor cells. Proc. Natl. Acad. Sci. USA 2012, 109, 2527-2532. [CrossRef] [PubMed]

20. Han, D.W.; Tapia, N.; Hermann, A.; Hemmer, K.; Höing, S.; Araúzo-Bravo, M.J.; Zaehres, H.; Wu, G.; Frank, S.; Moritz, S.; et al. Direct reprogramming of fibroblasts into neural stem cells by defined factors. Cell Stem Cell 2012, 10, 465-472. [CrossRef] [PubMed] 
21. Ring, K.L.; Tong, L.M.; Balestra, M.E.; Javier, R.; Andrews-Zwilling, Y.; Li, G.; Walker, D.; Zhang, W.R.; Kreitzer, A.C.; Huang, Y. Direct reprogramming of mouse and human fibroblasts into multipotent neural stem cells with a single factor. Cell Stem Cell 2012, 11, 100-109. [CrossRef] [PubMed]

22. Mitchell, R.R.; Szabo, E.; Benoit, Y.D.; Case, D.T.; Mechael, R.; Alamilla, J.; Lee, J.H.; Fiebig-Comyn, A.; Gillespie, D.C.; Bhatia, M. Activation of neural cell fate programs toward direct conversion of adult human fibroblasts into tri-potent neural progenitors using Oct-4. Stem Cells Dev. 2014, 23, 1937-1946. [CrossRef] [PubMed]

23. Lee, J.H.; Mitchell, R.R.; McNicol, J.D.; Shapovalova, Z.; Laronde, S.; Tanasijevic, B.; Milsom, C.; Casado, F.; Fiebig-Comyn, A.; Collins, T.J.; et al. Single transcription factor conversion of human blood fate to NPCs with CNS and PNS developmental capacity. Cell Rep. 2015, 11, 1367-1376. [CrossRef] [PubMed]

24. Wang, L.; Wang, L.; Huang, W.; Su, H.; Xue, Y.; Su, Z.; Liao, B.; Wang, H.; Bao, X.; Qin, D.; et al. Generation of integration-free neural progenitor cells from cells in human urine. Nat. Methods 2013, 10, 84-89. [CrossRef] [PubMed]

25. Campbell, K.H.; McWhir, J.; Ritchie, W.A.; Wilmut, I. Sheep cloned by nuclear transfer from a cultured cell line. Nature 1996, 380, 64-66. [CrossRef] [PubMed]

26. Tsubouchi, T.; Soza-Ried, J.; Brown, K.; Piccolo, F.M.; Cantone, I.; Landeira, D.; Bagci, H.; Hochegger, H.; Merkenschlager, M.; Fisher, A.G. DNA synthesis is required for reprogramming mediated by stem cell fusion. Cell 2013, 152, 873-883. [CrossRef] [PubMed]

27. Xie, F.; Tang, X.; Zhang, Q.; Deng, C. Reprogramming human adipose tissue stem cells using epidermal keratinocyte extracts. Mol. Med. Rep. 2015, 11, 182-188. [CrossRef] [PubMed]

28. Kadengodlu, P.A.; Rai, V.R. Role of nanotechnology in epigenetic reprogramming. Stem Cells Dev. 2015, 24, 535-549. [CrossRef] [PubMed]

29. Wilmut, I.; Schnieke, A.E.; McWhir, J.; Kind, A.J.; Campbell, K.H. Viable offspring derived from fetal and adult mammalian cells. Nature 1997, 385, 810-813. [CrossRef] [PubMed]

30. Gurdon, J.B.; Elsdale, T.R.; Fischberg, M. Sexually mature individuals of Xenopus laevis from the transplantation of single somatic nuclei. Nature 1958, 182, 64-65. [CrossRef] [PubMed]

31. Gurdon, J.B. The developmental capacity of nuclei taken from intestinal epithelium cells of feeding tadpoles. J. Embryol. Exp. Morphol. 1962, 10, 622-640. [PubMed]

32. Wernig, M.; Lengner, C.J.; Hanna, J.; Lodato, M.A.; Steine, E.; Foreman, R.; Staerk, J.; Markoulaki, S.; Jaenisch, R. A drug-inducible transgenic system for direct reprogramming of multiple somatic cell types. Nat. Biotechnol. 2008, 26, 916-924. [CrossRef] [PubMed]

33. Hockemeyer, D.; Soldner, F.; Cook, E.G.; Gao, Q.; Mitalipova, M.; Jaenisch, R. A drug-inducible system for direct reprogramming of human somatic cells to pluripotency. Cell Stem Cell 2008, 3, 346-353. [CrossRef] [PubMed]

34. Maherali, N.; Ahfeldt, T.; Rigamonti, A.; Utikal, J.; Cowan, C.; Hochedlinger, K. A high-efficiency system for the generation and study of human induced pluripotent stem cells. Cell Stem Cell 2008, 3, 340-345. [CrossRef] [PubMed]

35. Yamaguchi, S.; Hirano, K.; Nagata, S.; Tada, T. Sox2 expression effects on direct reprogramming efficiency as determined by alternative somatic cell fate. Stem Cell Res. 2011, 6, 177-186. [CrossRef] [PubMed]

36. Papapetrou, E.P.; Tomishima, M.J.; Chambers, S.M.; Mica, Y.; Reed, E.; Menon, J.; Tabar, V.; Mo, Q.; Studer, L.; Sadelain, M. Stoichiometric and temporal requirements of Oct4, Sox2, Klf4, and c-Myc expression for efficient human iPSC induction and differentiation. Proc. Natl. Acad. Sci. USA 2009, 106, 12759-12764. [CrossRef] [PubMed]

37. Buganim, Y.; Faddah, D.A.; Cheng, A.W.; Itskovich, E.; Markoulaki, S.; Ganz, K.; Klemm, S.L.; van Oudenaarden, A.; Jaenisch, R. Single-cell expression analyses during cellular reprogramming reveal an early stochastic and a late hierarchic phase. Cell 2012, 150, 1209-1222. [CrossRef] [PubMed]

38. Takahashi, K.; Tanabe, K.; Ohnuki, M.; Narita, M.; Sasaki, A.; Yamamoto, M.; Nakamura, M.; Sutou, K.; Osafune, K.; Yamanaka, S. Induction of pluripotency in human somatic cells via a transient state resembling primitive streak-like mesendoderm. Nat. Commun. 2014, 5, 3678. [CrossRef] [PubMed]

39. O’Malley, J.; Skylaki, S.; Iwabuchi, K.A.; Chantzoura, E.; Ruetz, T.; Johnsson, A.; Tomlinson, S.R.; Linnarsson, S.; Kaji, K. High-resolution analysis with novel cell-surface markers identifies routes to iPS cells. Nature 2013, 499, 88-91. [CrossRef] [PubMed] 
40. Ban, H.; Nishishita, N.; Fusaki, N.; Tabata, T.; Saeki, K.; Shikamura, M.; Takada, N.; Inoue, M.; Hasegawa, M.; Kawamata, S.; et al. Efficient generation of transgene-free human induced pluripotent stem cells (iPSCs) by temperature-sensitive Sendai virus vectors. Proc. Natl. Acad. Sci. USA 2011, 108, 14234-14239. [CrossRef] [PubMed]

41. Najm, F.J.; Lager, A.M.; Zaremba, A.; Wyatt, K.; Caprariello, A.V.; Factor, D.C.; Karl, R.T.; Maeda, T.; Miller, R.H.; Tesar, P.J. Transcription factor-mediated reprogramming of fibroblasts to expandable, myelinogenic oligodendrocyte progenitor cells. Nat. Biotechnol. 2013, 31, 426-433. [CrossRef] [PubMed]

42. Yang, N.; Zuchero, J.B.; Ahlenius, H.; Marro, S.; Ng, Y.H.; Vierbuchen, T.; Hawkins, J.S.; Geissler, R.; Barres, B.A.; Wernig, M. Generation of oligodendroglial cells by direct lineage conversion. Nat. Biotechnol. 2013, 31, 434-439. [CrossRef] [PubMed]

43. Soufi, A.; Donahue, G.; Zaret, K.S. Facilitators and impediments of the pluripotency reprogramming factors' initial engagement with the genome. Cell 2012, 151, 994-1004. [CrossRef] [PubMed]

44. Koche, R.P.; Smith, Z.D.; Adli, M.; Gu, H.; Ku, M.; Gnirke, A.; Bernstein, B.E.; Meissner, A. Reprogramming factor expression initiates widespread targeted chromatin remodeling. Cell Stem Cell 2011, 8, 96-105. [CrossRef] [PubMed]

45. Knoepfler, P.S.; Zhang, X.Y.; Cheng, P.F.; Gafken, P.R.; McMahon, S.B.; Eisenman, R.N. Myc influences global chromatin structure. EMBO J. 2006, 25, 2723-2734. [CrossRef] [PubMed]

46. Lin, C.Y.; Lovén, J.; Rahl, P.B.; Paranal, R.M.; Burge, C.B.; Bradner, J.E.; Lee, T.I.; Young, R.A. Transcriptional amplification in tumor cells with elevated c-Myc. Cell 2012, 151, 56-67. [CrossRef] [PubMed]

47. Nie, Z.; Hu, G.; Wei, G.; Cui, K.; Yamane, A.; Resch, W.; Wang, R.; Green, D.R.; Tessarollo, L.; Casellas, R.; et al. c-Myc is a universal amplifier of expressed genes in lymphocytes and embryonic stem cells. Cell 2012, 151, 68-79. [CrossRef] [PubMed]

48. Yu, J.; Vodyanik, M.A.; Smuga-Otto, K.; Antosiewicz-Bourget, J.; Frane, J.L.; Tian, S.; Nie, J.; Jonsdottir, G.A.; Ruotti, V.; Stewart, R.; et al. Induced pluripotent stem cell lines derived from human somatic cells. Science 2007, 318, 1917-1920. [CrossRef] [PubMed]

49. Sablin, E.P.; Blind, R.D.; Uthayaruban, R.; Chiu, H.J.; Deacon, A.M.; Das, D.; Ingraham, H.A.; Fletterick, R.J. Structure of Liver Receptor Homolog-1 (NR5A2) with PIP3 hormone bound in the ligand binding pocket. J. Struct. Biol. 2015, 192, 342-348. [CrossRef] [PubMed]

50. Heng, J.C.; Feng, B.; Han, J.; Jiang, J.; Kraus, P.; Ng, J.H.; Orlov, Y.L.; Huss, M.; Yang, L.; Lufkin, T.; et al. The nuclear receptor $\mathrm{Nr} 5 \mathrm{a} 2$ can replace Oct4 in the reprogramming of murine somatic cells to pluripotent cells. Cell Stem Cell 2010, 6, 167-174. [CrossRef] [PubMed]

51. Shu, J.; Wu, C.; Wu, Y.; Li, Z.; Shao, S.; Zhao, W.; Tang, X.; Yang, H.; Shen, L.; Zuo, X.; et al. Induction of pluripotency in mouse somatic cells with lineage specifiers. Cell 2013, 153, 963-975. [CrossRef] [PubMed]

52. Nuria, M.; Emmanuel, N.; Ignacio, S.M.; Tomoaki, H.; Sachin, K.; Laia, M.; Carme, C.; Yuriko, H.; Yun, X. Tency with lineage specifiers. Cell Stem Cell 2013, 13, 341-350.

53. Feng, B.; Jiang, J.; Kraus, P.; Ng, J.H.; Heng, J.C.; Chan, Y.S.; Yaw, L.P.; Zhang, W.; Loh, Y.H.; Han, J.; et al. Reprogramming of fibroblasts into induced pluripotent stem cells with orphan nuclear receptor Esrrb. Nat. Cell Biol. 2009, 11, 197-203. [CrossRef] [PubMed]

54. Maekawa, M.; Yamaguchi, K.; Nakamura, T.; Shibukawa, R.; Kodanaka, I.; Ichisaka, T.; Kawamura, Y.; Mochizuki, H.; Goshima, N.; Yamanaka, S. Direct reprogramming of somatic cells is promoted by maternal transcription factor Glis1. Nature 2011, 474, 225-229. [CrossRef] [PubMed]

55. Cheval, L.; Pierrat, F.; Rajerison, R.; Piquemal, D.; Doucet, A. Of mice and men: Divergence of gene expression patterns in kidney. PLoS ONE 2012, 7, e46876. [CrossRef] [PubMed]

56. Balestrieri, C.; Vanoni, M.; Hautaniemi, S.; Alberghina, L.; Chiaradonna, F. Integrative transcriptional analysis between human and mouse cancer cells provides a common set of transformation associated genes. Biotechnol. Adv. 2012, 30, 16-29. [CrossRef] [PubMed]

57. Gul-Uludag, H.; Xu, P.; Marquez-Curtis, L.A.; Xing, J.; Janowska-Wieczorek, A.; Chen, J. Cationic liposome-mediated CXCR4 gene delivery into hematopoietic stem/progenitor cells: Implications for clinical transplantation and gene therapy. Stem Cells Dev. 2012, 21, 1587-1596. [CrossRef] [PubMed]

58. McLenachan, S.; Sarsero, J.P.; Ioannou, P.A. Flow-cytometric analysis of mouse embryonic stem cell lipofection using small and large DNA constructs. Genomics 2007, 89, 708-720. [CrossRef] [PubMed]

59. Ellis, J. Silencing and variegation of gammaretrovirus and lentivirus vectors. Hum. Gene Ther. 2005, 16, 1241-1246. [CrossRef] [PubMed] 
60. Follenzi, A.; Naldini, L. Generation of HIV-1 derived lentiviral vectors. Methods Enzymol. 2002, 346, 454-465. [PubMed]

61. Lotti, F.; Mavilio, F. The choice of a suitable lentivirus vector: Transcriptional targeting. Methods Mol. Biol. 2003, 229, 17-27. [PubMed]

62. Stadtfeld, M.; Nagaya, M.; Utikal, J.; Weir, G.; Hochedlinger, K. Induced pluripotent stem cells generated without viral integration. Science 2008, 322, 945-949. [CrossRef] [PubMed]

63. Zhou, W.; Freed, C.R. Adenoviral gene delivery can reprogram human fibroblasts to induced pluripotent stem cells. Stem Cells 2009, 27, 2667-2674. [CrossRef] [PubMed]

64. Thomas, C.E.; Ehrhardt, A.; Kay, M.A. Progress and problems with the use of viral vectors for gene therapy. Nat. Rev. Genet. 2003, 4, 346-358. [CrossRef] [PubMed]

65. Fusaki, N.; Ban, H.; Nishiyama, A.; Saeki, K.; Hasegawa, M. Efficient induction of transgene-free human pluripotent stem cells using a vector based on Sendai virus, an RNA virus that does not integrate into the host genome. Proc. Jpn. Acad. Ser. B Phys. Biol. Sci. 2009, 85, 348-362. [CrossRef] [PubMed]

66. Ruggieri, M.; Riboldi, G.; Brajkovic, S.; Bucchia, M.; Bresolin, N.; Comi, G.P.; Corti, S. Induced neural stem cells: Methods of reprogramming and potential therapeutic applications. Prog. Neurobiol. 2014, 114, 15-24. [CrossRef] [PubMed]

67. Yu, J.; Hu, K.; Smuga-Otto, K.; Tian, S.; Stewart, R.; Slukvin, I.I.; Thomson, J.A. Human induced pluripotent stem cells free of vector and transgene sequences. Science 2009, 324, 797-801. [CrossRef] [PubMed]

68. McClintock, B. The origin and behavior of mutable loci in maize. Proc. Natl. Acad. Sci. USA 1950, 36, 344-355. [CrossRef] [PubMed]

69. Jia, F.; Wilson, K.D.; Sun, N.; Gupta, D.M.; Huang, M.; Li, Z.; Panetta, N.J.; Chen, Z.Y.; Robbins, R.C.; Kay, M.A.; et al. A nonviral minicircle vector for deriving human iPS cells. Nat. Methods 2010, 7, 197-199. [CrossRef] [PubMed]

70. Narsinh, K.H.; Jia, F.; Robbins, R.C.; Kay, M.A.; Longaker, M.T.; Wu, J.C. Generation of adult human induced pluripotent stem cells using nonviral minicircle DNA vectors. Nat. Protoc. 2011, 6, 78-88. [CrossRef] [PubMed]

71. Schlaeger, T.M.; Daheron, L.; Brickler, T.R.; Entwisle, S.; Chan, K.; Cianci, A.; DeVine, A.; Ettenger, A.; Fitzgerald, K.; Godfrey, M.; et al. A comparison of non-integrating reprogramming methods. Nat. Biotechnol. 2015, 33, 58-63. [CrossRef] [PubMed]

72. Ogawa, H.; Wu, X.; Kawamoto, K.; Nishida, N.; Konno, M.; Koseki, J.; Matsui, H.; Noguchi, K.; Gotoh, N.; Yamamoto, T.; et al. MicroRNAs Induce Epigenetic Reprogramming and Suppress Malignant Phenotypes of Human Colon Cancer Cells. PLoS ONE 2015, 10, e0127119. [CrossRef] [PubMed]

73. Weide, B.; Garbe, C.; Rammensee, H.G.; Pascolo, S. Plasmid DNA- and messenger RNA-based anti-cancer vaccination. Immunol. Lett. 2008, 115, 33-42. [CrossRef] [PubMed]

74. Zhou, H.; Wu, S.; Joo, J.Y.; Zhu, S.; Han, D.W.; Lin, T.; Trauger, S.; Bien, G.; Yao, S.; Zhu, Y.; et al. Generation of induced pluripotent stem cells using recombinant proteins. Cell Stem Cell 2009, 4, 381-384. [CrossRef] [PubMed]

75. Li, G.H.; Li, W.; Mumper, R.J.; Nath, A. Molecular mechanisms in the dramatic enhancement of HIV-1 Tat transduction by cationic liposomes. FASEB J. 2012, 26, 2824-2834. [CrossRef] [PubMed]

76. Neumann, E.; Schaefer-Ridder, M.; Wang, Y.; Hofschneider, P.H. Gene transfer into mouse lyoma cells by electroporation in high electric fields. EMBO J. 1982, 1, 841-845. [PubMed]

77. Bhise, N.S.; Wahlin, K.J.; Zack, D.J.; Green, J.J. Evaluating the potential of poly ( $\beta$-amino ester) nanoparticles for reprogramming human fibroblasts to become induced pluripotent stem cells. Int. J. Nanomed. 2013, 8, 4641-4658.

78. Høffding, M.K.; Hyttel, P. Ultrastructural visualization of the Mesenchymal-to-Epithelial Transition during reprogramming of human fibroblasts to induced pluripotent stem cells. Stem Cell Res. 2015, 14, 39-53. [CrossRef] [PubMed]

79. Hotta, A.; Ellis, J. Retroviral vector silencing during iPS cell induction: An epigenetic beacon that signals distinct pluripotent states. J. Cell. Biochem. 2008, 105, 940-948. [CrossRef] [PubMed]

80. Tong, J.; Sun, D.; Yang, C.; Wang, Y.; Sun, S.; Li, Q.; Bao, J.; Liu, Y. Serum starvation and thymidine double blocking achieved efficient cell cycle synchronization and altered the expression of p27, p53, bcl-2 in canine breast cancer cells. Res. Vet. Sci. 2016, 105, 10-14. [CrossRef] [PubMed] 
81. Tsubouchi, T.; Fisher, A.G. Reprogramming and the pluripotent stem cell cycle. Curr. Top. Dev. Biol. 2013, 104, 223-241. [PubMed]

82. Chen, M.; Huang, J.; Yang, X.; Liu, B.; Zhang, W.; Huang, L.; Deng, F.; Ma, J.; Bai, Y.; Lu, R.; et al. Serum starvation induced cell cycle synchronization facilitates human somatic cells reprogramming. PLoS ONE 2012, 7, e28203. [CrossRef] [PubMed]

83. Ruiz, S.; Panopoulos, A.D.; Herrerías, A.; Bissig, K.D.; Lutz, M.; Berggren, W.T.; Verma, I.M.; Izpisua Belmonte, J.C. A high proliferation rate is required for cell reprogramming and maintenance of human embryonic stem cell identity. Curr. Biol. 2011, 21, 45-52. [CrossRef] [PubMed]

84. Feng, J. Kinetic barriers in transdifferentiation. Cell Cycle 2016, 22, 1-2. [CrossRef] [PubMed]

85. Lee, J.; Go, Y.; Kang, I.; Han, Y.M.; Kim, J. Oct-4 controls cell-cycle progression of embryonic stem cells. Biochem. J. 2010, 426, 171-181. [CrossRef] [PubMed]

86. Zhang, X.; Neganova, I.; Przyborski, S.; Yang, C.; Cooke, M.; Atkinson, S.P.; Anyfantis, G.; Fenyk, S.; Keith, W.N.; Hoare, S.F.; et al. A role for NANOG in G1 to $S$ transition in human embryonic stem cells through direct binding of CDK6 and CDC25A. J. Cell Biol. 2009, 184, 67-82. [CrossRef] [PubMed]

87. Card, D.A.; Hebbar, P.B.; Li, L.; Trotter, K.W.; Komatsu, Y.; Mishina, Y.; Archer, T.K. Oct4/Sox2-regulated miR-302 targets cyclin D1 in human embryonic stem cells. Mol. Cell. Biol. 2008, 28, 6426-6438. [CrossRef] [PubMed]

88. Lange, C.; Huttner, W.B.; Calegari, F. Cdk4/cyclinD1 overexpression in neural stem cells shortens G1, delays neurogenesis, and promotes the generation and expansion of basal progenitors. Cell Stem Cell 2009, 5, 320-331. [CrossRef] [PubMed]

89. Weinberg, R.A. The retinoblastoma protein and cell cycle control. Cell 1995, 81, 323-330. [CrossRef]

90. Malumbres, M.; Barbacid, M. Cell cycle, CDKs and cancer: A changing paradigm. Nat. Rev. Cancer 2009, 9, 153-166. [CrossRef] [PubMed]

91. Ma, Y.; Kanakousaki, K.; Buttitta, L. How the cell cycle impacts chromatin architecture and influences cell fate. Front. Genet. 2015, 6, 19. [CrossRef] [PubMed]

92. Chung, H.C.; Lin, R.C.; Logan, G.J.; Alexander, I.E.; Sachdev, P.S.; Sidhu, K.S. Human induced pluripotent stem cells derived under feeder-free conditions display unique cell cycle and DNA replication gene profiles. Stem Cells Dev. 2012, 21, 206-216. [CrossRef] [PubMed]

93. Petruk, S.; Sedkov, Y.; Johnston, D.M.; Hodgson, J.W.; Black, K.L.; Kovermann, S.K.; Beck, S.; Canaani, E.; Brock, H.W.; Mazo, A. TrxG and PcG proteins but not methylated histones remain associated with DNA through replication. Cell 2012, 150, 922-933. [CrossRef] [PubMed]

94. Shibahara, K.; Stillman, B. Replication-dependent marking of DNA by PCNA facilitates CAF-1-coupled inheritance of chromatin. Cell 1999, 96, 575-585. [CrossRef]

95. Rountree, M.R.; Bachman, K.E.; Baylin, S.B. DNMT1 binds HDAC2 and a new co-repressor, DMAP1, to form a complex at replication foci. Nat. Genet. 2000, 25, 269-277. [CrossRef] [PubMed]

96. Yoshida, Y.; Takahashi, K.; Okita, K.; Ichisaka, T.; Yamanaka, S. Hypoxia enhances the generation of induced pluripotent stem cells. Cell Stem Cell 2009, 5, 237-241. [CrossRef] [PubMed]

97. Liu, S.P.; Fu, R.H.; Wu, D.C.; Hsu, C.Y.; Chang, C.H.; Lee, W.; Lee, Y.D.; Liu, C.H.; Chien, Y.J.; Lin, S.Z.; et al . Mouse-induced pluripotent stem cells generated under hypoxic conditions in the absence of viral infection and oncogenic factors and used for ischemic stroke therapy. Stem Cells Dev. 2014, 23, 421-433. [CrossRef] [PubMed]

98. Mikkelsen, T.S.; Hanna, J.; Zhang, X.; Ku, M.; Wernig, M.; Schorderet, P.; Bernstein, B.E.; Jaenisch, R.; Lander, E.S.; Meissner, A. Dissecting direct reprogramming through integrative genomic analysis. Nature 2008, 454, 49-55. [CrossRef] [PubMed]

99. Xu, X.L.; Yang, J.P.; Fu, L.N.; Ren, R.T.; Yi, F.; Suzuki, K.; Liu, K.; Ding, Z.C.; Qu, J.; Zhang, W.Q.; et al. Direct reprogramming of porcine fibroblasts to neural progenitor cells. Protein Cell 2014, 5, 4-7. [CrossRef] [PubMed]

100. Meyer, S.; Wörsdörfer, P.; Günther, K.; Thier, M.; Edenhofer, F. Derivation of Adult Human Fibroblasts and their Direct Conversion into Expandable Neural Progenitor Cells. J. Vis. Exp. 2015, e52831. [CrossRef] [PubMed]

101. Su, G.; Zhao, Y.; Wei, J.; Xiao, Z.; Chen, B.; Han, J.; Chen, L.; Guan, J.; Wang, R.; Dong, Q.; et al. Direct conversion of fibroblasts into neural progenitor-like cells by forced growth into 3D spheres on low attachment surfaces. Biomaterials 2013, 34, 5897-5906. [CrossRef] [PubMed] 
102. Li, W.; Li, K.; Wei, W.; Ding, S. Chemical approaches to stem cell biology and therapeutics. Cell Stem Cell 2013, 13, 270-283. [CrossRef] [PubMed]

103. Yu, C.; Liu, K.; Tang, S.; Ding, S. Chemical approaches to cell reprogramming. Curr. Opin. Genet. Dev. 2014, 28, 50-56. [CrossRef] [PubMed]

104. Biswas, D.; Jiang, P. Chemically induced reprogramming of somatic cells to pluripotent stem cells and neural cells. Int. J. Mol. Sci. 2016, 17. [CrossRef] [PubMed]

105. Soufi, A. Mechanisms for enhancing cellular reprogramming. Curr. Opin. Genet. Dev. 2014, 25, $101-109$. [CrossRef] [PubMed]

106. Huangfu, D.; Maehr, R.; Guo, W.; Eijkelenboom, A.; Snitow, M.; Chen, A.E.; Melton, D.A. Induction of pluripotent stem cells by defined factors is greatly improved by small-molecule compounds. Nat. Biotechnol. 2008, 26, 795-797. [CrossRef] [PubMed]

107. Mali, P.; Chou, B.K.; Yen, J.; Ye, Z.; Zou, J.; Dowey, S.; Brodsky, R.A.; Ohm, J.E.; Yu, W.; Baylin, S.B.; et al. Butyrate greatly enhances derivation of human induced pluripotent stem cells by promoting epigenetic remodeling and the expression of pluripotency-associated genes. Stem Cells 2010, 28, 713-720. [CrossRef] [PubMed]

108. He, Y.F.; Li, B.Z.; Li, Z.; Liu, P.; Wang, Y.; Tang, Q.; Ding, J.; Jia, Y.; Chen, Z.; Li, L.; et al. Tet-mediated formation of 5-carboxylcytosine and its excision by TDG in mammalian DNA. Science 2011, 333, 1303-1307. [CrossRef] [PubMed]

109. Tahiliani, M.; Koh, K.P.; Shen, Y.; Pastor, W.A.; Bandukwala, H.; Brudno, Y.; Agarwal, S.; Iyer, L.M.; Liu, D.R.; Aravind, L.; et al. Conversion of 5-methylcytosine to 5-hydroxymethylcytosine in mammalian DNA by MLL partner TET1. Science 2009, 324, 930-935. [CrossRef] [PubMed]

110. Gao, Y.; Chen, J.; Li, K.; Wu, T.; Huang, B.; Liu, W.; Kou, X.; Zhang, Y.; Huang, H.; Jiang, Y.; et al. Replacement of Oct4 by Tet1 during iPSC induction reveals an important role of DNA methylation and hydroxymethylation in reprogramming. Cell Stem Cell 2013, 12, 453-469. [CrossRef] [PubMed]

111. Blaschke, K.; Ebata, K.T.; Karimi, M.M.; Zepeda-Martínez, J.A.; Goyal, P.; Mahapatra, S.; Tam, A.; Laird, D.J.; Hirst, M.; Rao, A.; et al. Vitamin C induces Tet-dependent DNA demethylation and a blastocyst-like state in ES cells. Nature 2013, 500, 222-226. [CrossRef] [PubMed]

112. Li, Y.; Zhang, Q.; Yin, X.; Yang, W.; Du, Y.; Hou, P.; Ge, J.; Liu, C.; Zhang, W.; Zhang, X.; et al. Generation of iPSCs from mouse fibroblasts with a single gene, Oct4, and small molecules. Cell Res. 2011, 21, 196-204. [CrossRef] [PubMed]

113. Miranda, T.B.; Cortez, C.C.; Yoo, C.B.; Liang, G.; Abe, M.; Kelly, T.K.; Marquez, V.E.; Jones, P.A. DZNep is a global histone methylation inhibitor that reactivates developmental genes not silenced by DNA methylation. Mol. Cancer Ther. 2009, 8, 1579-1588. [CrossRef] [PubMed]

114. Tam, E.K.; Li, Z.; Goh, Y.L.; Cheng, X.; Wong, S.Y.; Santhanakrishnan, S.; Chai, C.L.; Yao, S.Q. Cell-based proteome profiling using an affinity-based probe (AfBP) derived from 3-deazaneplanocin A (DzNep). Chem. Asian J. 2013, 8, 1818-1828. [CrossRef] [PubMed]

115. Folmes, C.D.; Nelson, T.J.; Martinez-Fernandez, A.; Arrell, D.K.; Lindor, J.Z.; Dzeja, P.P.; Ikeda, Y.; Perez-Terzic, C.; Terzic, A. Somatic oxidative bioenergetics transitions into pluripotency- dependent glycolysis to facilitate nuclear reprogramming. Cell Metab. 2011, 14, 264-271. [CrossRef] [PubMed]

116. Zhu, S.; Ambasudhan, R.; Sun, W.; Kim, H.J.; Talantova, M.; Wang, X.; Zhang, M.; Zhang, Y.; Laurent, T.; Parker, J.; et al. Small molecules enable Oct4-mediated direct reprogramming into expandable human neural stem cells. Cell Res. 2014, 24, 126-129. [CrossRef] [PubMed]

117. Han, Y.C.; Lim, Y.; Duffieldl, M.D.; Li, H.; Liu, J.; Abdul Manaph, N.P.; Yang, M.; Keating, D.J.; Zhou, X.F. Direct reprogramming of mouse fibroblasts to neural stem cells by small molecules. Stem Cells Int. 2016, 2016, 4304916. [CrossRef] [PubMed]

(C) 2016 by the authors; licensee MDPI, Basel, Switzerland. This article is an open access article distributed under the terms and conditions of the Creative Commons Attribution (CC-BY) license (http:/ / creativecommons.org/licenses/by/4.0/). 